\title{
0 Discurso Político Monarquiano e a Recepção do Conceito de Poder Moderador no Brasil (1822-1824)
}

\author{
Christian Edward Cyril Lynch
}

\section{INTRODUÇÃO}

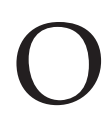

objetivo deste artigo é revisitar o momento fundador das instituições políticas brasileiras para identificar, junto aos conselheiros da Coroa imperial, a pregnância do discurso monarquiano francês ${ }^{1}$ que, no início da Revolução Francesa, buscara justificar politicamente a preeminência do Executivo sobre o Legislativo e atribuir-lhe o papel de principal representante da soberania nacional. A provável preferência da Constituinte por um modelo institucional mais próximo ao da Constituição francesa de 1791 e que, reproduzido na Ibéria, invertia aquelas relações de hegemonia entre os poderes, levou porém os conselheiros da Coroa a mobilizarem a categoria de Poder Moderador tal como desenvolvida pela escola ultraliberal francesa no início da Restauração. Embora o discurso de Benjamin Constant pretendesse afastar o monarca do exercício direto do Poder Executivo para atribuir-lhe apenas o papel de árbitro do sistema político, as salvaguardas por ele requeridas para que a Coroa pudesse exercer o Poder Moderador continham argumentos valiosos para que dela os governistas brasileiros lançassem mão, com o fito porém contrário de preservar a inteireza das prerrogativas régias diante das crescentes pretensões da Assembléia de monopólio da representação da soberania. A defesa pública de um projeto constitucional monarquiano, a partir do conceito ultraliberal

DADOS - Revista de Ciências Sociais, Rio de Janeiro, Vol. 48, nº3, 2005, pp. 611 a 654. 
de Poder Moderador, acabou por fazer com que este último adquirisse no Brasil alguns significados diversos daqueles a que estava associado na França, como os de neutralidade ativa, discricionariedade decisionista e centralização político-administrativa, significados que, com o tempo, passaram a ser associados às próprias características que o Estado brasileiro deveria apresentar perante os desafios da construção nacional. Essa ambigüidade jurídico-doutrinária em torno do Poder Moderador se refletiu no texto constitucional de 1824, o qual passou a comportar, conseqüentemente, duas leituras. Na primeira, de cunho ultraliberal, o Imperador figurava apenas de árbitro do sistema constitucional, ao passo que, na segunda, monarquiana, o chefe de Estado era apresentado como o eixo de toda a atividade governamental. Essa dualidade estaria na raiz das tensões do pensamento político brasileiro, tradicionalmente premido entre um modelo liberal, mas oligárquico, e outro autoritário, mas modernizador.

Do ponto de vista metodológico, fui livremente guiado por duas referências principais. A primeira é do contextualismo lingüístico, na variante discursiva desenvolvida por John Pocock (1975). Buscando seguir certos parâmetros por ele adotados, tento aqui identificar, nos atos de fala dos atores envolvidos na luta política de determinados lugar e período (Rio de Janeiro, 1822-1824), a presença de conceitos e argumentos característicos de discursos políticos anteriormente e alhures elaborados 1789-1791, Paris). Isto feito, ensaio reconstituir contextualmente a trajetória dessa recepção e compreender como a circunstância, a necessidade e a contingência levaram esses atores a lançarem mão de tais conceitos e eventualmente imprimir-lhes novos significados. Por outro lado, a ênfase que vou conferir ao exame do dispositivo institucional, que deveria necessariamente resultar da aclimatação daquele discurso, relacionando-o, na conclusão, com certas representações que a sociedade brasileira passou a fazer de si mesma, me aproxima da história conceitual do político de Pierre Rosanvallon. O estudo da democracia exigiria o das representações sociais na medida em que a própria categoria de povo, sujeito ativo e passivo dessa forma de sociedade, dependeria das idéias de que ele se formula na tentativa de se tornar inteligível a si mesmo enquanto comunidade política. Essas representações sociais inevitavelmente se refletem nas concepções institucionais adotadas na democracia, pois que somente elas são capazes de conferir exterioridade e, portanto, visibilidade funcional e simbólica às idéias que a comunidade nutre a respeito do exercício adequado do poder público (Rosanvallon, 2002). Nesse sentido, penso que a persistência de cer- 
tas concepções de poder no debate brasileiro pode corresponder a uma igual persistência de certas auto-representações do povo e suas elites enquanto comunidade política. Se a hipótese estiver correta, seria então possível identificar historicamente os caminhos e descaminhos do percurso democrático da nação nos eventuais espaços de indeterminação entre instituições políticas concretas e representações sociais do poder.

\section{O PROJETO POLÍTICO MONARQUIANO E O CONCEITO DE PODER MODERADOR NA FRANÇA REVOLUCIONÁRIA}

Conforme demonstrou Marcel Gauchet (1995), todo o debate político francês durante a Revolução de 1789 foi atravessado pela persistente busca de um terceiro poder que, acima do Executivo e do Legislativo, fosse capaz de mantê-los nos limites previamente definidos na ordem constitucional. Era a lógica do sistema representativo o qual impunha a criação de mecanismos que permitissem ao povo soberano velar para que a vontade de seus mandatários não extrapolasse os limites do mandato que lhes havia outorgado. Haja vista que na Constituição, produto do Poder Constituinte, era reputada a expressão máxima da vontade do povo, a solução do impasse passava pela criação de um órgão superior aos demais poderes constituídos, encarregado de exercer sobre os atos por eles praticados um controle de constitucionalidade estrutural ou normativo. Chamaram-no Poder Regulador, Poder Moderador, Poder Preservador, Poder Neutro, Poder Real, atribuindo-o ao monarca, a um conselho, a um tribunato ou uma segunda câmara. As mais profundas reflexões dentre as inúmeras propostas então apresentadas foram as do abade Sieyès e de Benjamin Constant (Dupuy e Morabito, 1995) e do Consulado. O primeiro cogitou de um conselho constitucional encarnado em um Júri ou em um Senado (Bredin, 1988). O segundo desenvolveu idéia semelhante, abandonando-a, porém, quando da queda do Império em favor da do monarca constitucional como poder neutro ou moderador, que deveria manter-se afastado das atividades governamentais na qualidade de árbitro do sistema político (Constant, 1997). Foi Thiers quem, quinze anos depois, consagrou o slogan famoso pelo qual ficaria conhecida aquela interpretação liberal do papel do rei constitucional durante o século XIX: "o rei reina e não governa". O conceito de Poder Moderador ocupou lugar relevante no debate liberal francês até pelo menos a década de 1870, como se percebe nos textos de Laboulaye e de Prévost-Paradol (Paradol, 1981). Nos 
países ibéricos, por sua vez, o conceito continuaria central até pelo menos as primeiras décadas do século XX.

O conceito de Poder Moderador na Europa difundiu-se em setembro de 1789 durante a discussão sobre a organização dos poderes e suas relações recíprocas na Assembléia Constituinte francesa. A questão do bicameralismo e do direito de veto suscitaram, então, vivos debates sobre a função do rei na nova ordem constitucional. Na verdade, tratava-se de definir que poder do Estado haveria de, prioritariamente, representar a vontade soberana do povo e, a partir daí, definir a distribuição do poder político entre as demais instituições. Duas propostas constitucionais então se enfrentaram. A primeira, tributária do republicanismo de Rousseau e Mably, e encabeçada então por Sièyes, dispensava toda a noção de equilíbrio de poderes e de sua interconexão por mecanismos de freios e contrapesos. O modelo da Constituição inglesa, complicado maquinário para coibir ou amenizar as sobrevivências da opressão feudal, não se justificava na França, onde a ruptura completa com a feudalidade estava inscrita no próprio programa da Revolução (Sièyes, 2001:41). Entendendo que a função da representação era a de encarnar, em um órgão do Estado, a unidade da soberania absoluta da nação, Sièyes e Le Chapelier defenderam, então, um arcabouço constitucional no qual uma assembléia unicameral, eleita por todo o país, haveria de enfeixar em suas mãos todas as prerrogativas inerentes à soberania, a principal das quais era o monopólio da produção legislativa ${ }^{2}$. No contexto desse modelo constitucional monista, ao rei caberia o subordinado papel de mero comissário, isto é, de simples executor das leis determinadas pelo Legislativo, que não poderia portanto dissolver, e cujos projetos de lei não poderia vetar. Por um lado, não sendo eleito nem pertencendo à Assembléia, o rei não poderia interferir no processo legislativo, constituindo o veto um "mecanismo estranho" na máquina constitucional que, se exercido, seria uma "verdadeira lettre de cachet lançada contra a vontade nacional" (Sièyes, 1996:408). Era um modelo de República com rei ou, para usar a expressão de François Furet, de monarquia republicana (Furet e Halévi, 1996). Como não era admitida a hipótese de um poder constituído superior ao Legislativo, era a lógica da representação como encarnação da unidade da soberania absoluta que impedia nessa proposta a existência de um controle da constitucionalidade, isto é, um Poder Moderador. 
Embora também admitisse a soberania nacional como princípio de legitimidade da ordem política, a segunda proposta constitucional negava-se, porém, a associá-la à incontrastável supremacia de um Poder Legislativo unicameral, preferindo um Estado constitucional em que coubesse, ao contrário, à Coroa o papel de guardiã dos interesses nacionais. Os maiores defensores dessa proposta achavam-se no chamado partido monarquiano, grupo dos patriotas moderados dentre os quais figuravam Pierre-Victor Malouet, Jean-Joseph Mounier, o marquês de Lally-Tollendal e o visconde de Clermont-Tonnerre. As teses desse partido eram freqüentemente apoiadas por Mirabeau e por Jacques Necker, barão de Coppet, último ministro influente do Antigo Regime (Bredin, 1988:203). Tratava-se de inaugurar a modernidade política na França, sem todavia fazer uma completa tabula rasa do passado, já que "os franceses não são um povo novo, saído recentemente do fundo das florestas para formar uma associação, mas uma grande sociedade [...] que quer reestreitar os vínculos que unem todas as suas partes, que quer regenerar o reino, para quem os princípios da verdadeira monarquia serão para sempre sagrados" (Mounier, 1996:315). Os monarquianos rechaçavam doutrinas que resultassem em demasiada fragmentação do poder, seja entre facções de uma mesma assembléia, que prejudicariam a ordem administrativa, seja que preconizassem o retorno a um regime estamental.

Se o pensamento de Sièyes, nesse aspecto, remontava a Rousseau, o discurso político monarquiano remontava ao despotismo ilustrado de Helvétius e Voltaire, os quais viam em um Executivo forte encarnado na Coroa o único Poder capaz de superar os impasses da sociedade estamental e proceder à modernização do Reino. Essa orientação havia sido transmitida a Turgot e a seus sucessores, que, instalados nos postos de ministros do rei, haviam buscado auto-reformar o Antigo Regime a partir de uma concepção administrativista do poder público. Ao pretenderem transplantar para o interior do constitucionalismo calcado na soberania nacional a tese de "um poder monárquico reforçado, capaz de representar a nação como um todo e inteira, às expensas das pretensões da assembléia de querer encarnar a soberania nacional" (Griffiths, 1988:87), os monarquianos revelaram-se herdeiros desse reformismo modernizador ministerialista, sem que seu discurso pudesse, entretanto, ser incluído na categoria de absolutismo. Tanto assim que as formas institucionais por eles advogadas eram compatíveis com a descrição que Montesquieu fizera do governo inglês quarenta anos antes, eles puderam dourar a pílula de sua concepção constitucional 
ancorada em uma Coroa forte, acenando todavia com os argumentos mecanicistas e equilibrados da Constituição inglesa, certamente mais palatáveis para o público revolucionário, descritos em $O$ Espírito das Leis $^{3}$. A pedra de toque de toda a argumentação monarquiana residia na tese de que a nação soberana, ao eleger seus representantes e exprimir suas aspirações nos cadernos de queixas (cahiers de doléances), demonstrara não ter em nenhum momento pretendido atribuir o seu exercício somente à Assembléia nacional, tendo-o também delegado ao rei.

"Pode-se dizer com razão que os deputados escolhidos nos diferentes distritos não são os únicos representantes do povo; que o rei é o seu primeiro delegado; que ele é também representante do povo em todas as outras partes da autoridade que lhe foi confiada, e que o povo os encarregou conjuntamente de exprimir a vontade geral; que assim, quando o rei não dá sua sanção, ele não resiste à vontade geral, que ainda não está formada" (Mounier, 1996:400).

Foi precisamente a defesa do veto absoluto do rei que deixou transparecer o lugar de centralidade da Coroa dentro do Estado constitucional monarquiano. Por meio do poder de veto, mas também da dissolução da câmara baixa, o rei, chefe do Executivo, também participava do processo legislativo, valendo-se da prerrogativa monárquica para, na qualidade de primeiro representante da nação, defender o interesse público materializado na constituição contra as possíveis inconstâncias, excessos ou facciosismo do Poder Legislativo. Era o rei, sensível à opinião pública, quem poderia melhor interpretar seus sentimentos e defender a constituição contra as invasões dos demais poderes, convertendo-se em uma "poderosa barreira ao pé da qual se reunirão todos os verdadeiros amigos da ordem e da liberdade" (idem:401). Ele era "o representante perpétuo do povo", cuja prerrogativa era essencial para se evitar que a nascente classe política, surgida da representação eletiva, acabasse por constituir uma nova aristocracia; era o único, dentre os poderes constituídos, capaz de "manter o equilíbrio e impedir as parcialidades", tendo, nos momentos de crise, força e prestígio suficientes para "reunir todas as partes e voltar aquela atividade para um centro comum" (Mirabeau, 1996:370). As prerrogativas monárquicas de veto legislativo e de dissolução da câmara baixa - sucedida esta pela imediata convocação de novas eleições - eram verdadeiras formas de apelo ao povo soberano, sem as quais não haveria, segundo Lally-Tollendal, "obstáculo insuperável às investidas do poder legislativo contra o po- 
der executivo, à invasão, à confusão dos poderes, por conseguinte à derrubada da constituição e à opressão do povo" (Bredin, 1988:203). Nessa categoria de supremo representante e o principal intérprete do bem comum, Malouet chegaria ao extremo de defender o direito do rei recusar a própria Constituição elaborada pela Assembléia, se a entendesse lesiva ao interesse do povo, a ele recorrendo para que decidisse a questão (Malouet, 1996:368).

Como se vê, na concepção institucional monarquiana, o rei exercia, além do Poder Executivo, outras atribuições que com ele não se confundiam, embora também vinculadas à prerrogativa monárquica. Elas permitiam-lhe interferir extraordinariamente na esfera de outras agências para salvaguardar a ordem constitucional expressiva da vontade soberana, sempre que a necessidade pública assim o exigisse. A tradição da unidade nacional representada no corpo do chefe do Estado, detectada por Kantorowicz na própria origem do Estado, era assim naturalmente posta a serviço da nova concepção de soberania, para exercer um controle político-estrutural da constitucionalidade. Foi Bernardin de Saint-Pierre quem, no auge do debate, em setembro de 1789, melhor exprimiu essa lógica, naquela que possivelmente foi pela primeira vez empregada a expressão Poder Moderador:

"Muitos escritores célebres consideram o poder nacional na monarquia como dividido em dois, o poder legislativo e o poder executivo. Eles atribuem o primeiro à nação e o segundo ao rei. Essa divisão me parece insuficiente, porque falta um terceiro poder, necessário a todo o bom governo, o poder moderador, que pertence essencialmente ao rei na monarquia. O rei, aí, não é apenas um comissário da nação, um doge ou um stadthouder; é um monarca encarregado de dirigir suas operações [...]. Os três corpos da monarquia reagem sem cessar uns contra os outros, de sorte que, deixados a si mesmos, logo ocorreria que um deles oprimiria os outros dois, ou seria por eles oprimido [...]. Falta portanto que o rei tenha ainda o poder moderador, isto é, o de manter o equilíbrio entre esses corpos [...]. Como o rei tem, de direito, o poder executivo, não poderá haver lei alguma aprovada sua sanção; como ele tem também o poder moderador, esta assembléia, sendo formada de dois poderios cujos interesses são opostos, ele terá sempre o poder de manter o equilíbrio dela" (Saint-Pierre, 1819:64).

Embora derrotados pelo "monarquismo republicano" de Sièyes, os monarquianos que sobreviveram ao Terror perseveraram em suas idéias, na legalidade e fora dela, na França e no exílio, durante todo o perío- 
do da Revolução. Suas idéias foram se tornando mais claras à medida do desenrolar dos eventos - e foi assim que os monarquianos sobreviventes, como Mounier e Malouet, acabaram por se acomodar com o regime bonapartista, em cuja administração passaram a colaborar. Esse regime correspondia, grosso modo, à demanda modernizadora que eles haviam sustentado alguns anos antes: monarca como representante primeiro da soberania nacional; administração racionalizada, legislação unificada; ordem pública; Executivo forte; Legislativo subordina$\mathrm{do}^{4}$.

Ora, foi em uma intenção semelhante e sob o mesmo nome que o conceito apareceu pela primeira vez no debate brasileiro, em 1823. Ele foi então introduzido pela imprensa e na Constituinte por partidários do governo imperial, que pretendiam consolidar uma interpretação do papel institucional da Coroa capaz de evitar que ela fosse reduzida por seus oponentes a um apêndice do Poder Legislativo.

\section{A ELITE COIMBRÃ: O MONARQUIANISMO ENQUANTO DISCURSO DA CONSTRUÇÃO NACIONAL}

Foi uma forma de reformismo ministerialista inspirado no despotismo esclarecido que orientou diversos membros da alta burocracia luso-brasileira. Ele provinha dos planos da Academia Real de Ciências de Lisboa, que, encabeçada por Dom Rodrigo de Sousa Coutinho, Conde de Linhares, elaborara estratégias de superação do atraso científico e econômico do Império português. Linhares havia conhecido a França de Luís XVI, travado contato com intelectuais, como Raynal, e admirado os esforços de Necker para modernizar a máquina pública e instaurar o sistema representativo, deplorando o desperdício e a desordem do Antigo Regime (Funchal, 1908:193). Se por um lado tais estadistas propunham medidas politicamente mais "progressistas" do que as de Pombal, como a liberdade de imprensa (idem:341), eles todavia partilhavam da visão pombalina quanto ao papel central a ser desempenhado pelo Estado enquanto agente de transformações socioeconômicas (Maxwell, 2001). Embora suas propostas reformistas não tivessem obtido receptividade da parte de Dom João VI, quando irrompeu a Revolução Constitucionalista do Porto, diante da impotência da realeza perante o movimento e premidos pela necessidade de brecar as veleidades de seus opositores, foram aqueles reformistas quem se dedicaram à formulação de um projeto de sistema representativo em que o príncipe - e não a Assembléia - figurasse como o principal representante da 
soberania nacional. Dentre os estilos de liberalismo disponíveis, que nem sempre se reconheciam e se combatiam - o republicano norte-americano, à Madison; o monarquiano de Malouet e Mounier, o racionalista de ideólogos como Sièyes e Destutt de Tracy; o ultraliberal à Stäel e Constant--, o monarquiano era aquele que melhor correspondia às suas preferências na medida em que transportava o ideal modernizador ordeiro do despotismo esclarecido para o quadro do sistema constitucional. Os objetivos políticos da chamada "elite coimbrã" eram, portanto, similares aos dos monarquianos de 1789 - impedir o regime de assembléia única, cuja pretensão de preponderância sobre o rei era justificada a partir de sua pretensa qualidade de depositária exclusiva da soberania nacional. Adotado na França (1791) e depois reproduzido na Espanha (1812) e em Portugal (1822), esse modelo teria sempre fracassado com resultados desastrosos para a ordem pública. Daí que, na Constituinte do Brasil independente, políticos como José Bonifácio de Andrada e Silva, Antônio Carlos de Andrada Machado, Severiano Maciel da Costa, José Joaquim Carneiro de Campos e José da Silva Lisboa preferiram, ao contrário, sustentar um projeto caracterizado por uma Coroa forte.

Esse grupo de governistas da chamada elite coimbrã mobilizou, então, argumentos que, embora também extraídos do repertório liberal, eram porém bastante diferentes daqueles de seus adversários, os integrantes da chamada "elite brasiliense" ${ }^{5}$, que gravitava em torno de Gonçalves Ledo e Januário da Cunha Barbosa, e concebia o poder como algo próximo à monarquia republicana de Sièyes. Os "brasilienses" eram tachados de republicanos, democratas e jacobinos pelos monarquianos, ao passo que estes eram acusados por aqueles de corcundas, pés-de-chumbo ou simplesmente absolutistas (Lustosa, 2000). O projeto dos coimbrãos caracterizava-se por ser mais centralizador do que federativo, mais monárquico do que parlamentar e mais estatizante do que aquele de seus adversários. Por outro lado, dada a sua maior proximidade da Coroa, o menor peso dos interesses particulares na visão de mundo dos coimbrãos conferia-lhes maior sensibilidade quanto a temas estratégicos da construção do novo Império, o que se refletia na conveniência de abolir o tráfico de escravos e induzir a imigração européia. A elite coimbrã via no escravismo um obstáculo à modernização do Brasil, que poderia ocorrer apenas com trabalho metódico, disciplinado e assalariado (Oliveira, 1999:118). Esse não era o caso da elite brasiliense, mais representativa dos interesses da lavoura e que, entendendo mais rentável a continuidade pura e simples do sistema escra- 
vocrata, passou a temer medidas que acabassem por comprometê-lo. A promoção da colonização por suíços no interior da capitania do Rio de Janeiro, por meio do aumento de imposto sobre a comercialização de escravos, levou os brasilienses a condenar a interferência do Estado na economia por meio de um discurso liberal econômico que implicava submeter o Estado aos interesses da lavoura (idem:120). Por outro lado, coimbrãos como José Bonifácio de Andrada e Silva e José Severiano Maciel da Costa, acusados de "fautores do despotismo" pelo "progressismo" brasiliense, apresentavam projetos de extinção do tráfico negreiro $^{6}$. Daí que, entre os chamados democratas da elite brasiliense, "contavam-se grandes senhores de terra e comerciantes portugueses e [...] de sua agenda de reivindicações políticas nunca constou a libertação dos escravos" (Lustosa, 2000:334).

Eram, portanto, duas diferentes propostas liberais para o país recém-saído do status colonial. A primeira era tributária do despotismo esclarecido, de retórica realista, centrada na autoridade monárquica como representante da soberania nacional, centralizadora, estatizante, interventora, tutelar - em uma palavra, em que o político prevalecia sobre o econômico; enquanto a segunda, tributária do liberalismo de tendência democratizante, de retórica idealista, parlamentar, descentralizadora, era calcada nos interesses diretos da grande lavoura e da "sociedade civil" que ela dizia representar - em suma, um discurso em que o econômico prevalecia sobre o político. Tais concepções se chocariam já na Assembléia Constituinte de 1823, antecipando algumas das diferenças que, no decorrer do século XIX, seriam associadas aos partidos Conservador e Liberal ${ }^{7}$.

O projeto coimbrão encontrou seu maior expoente em um amigo e antigo discípulo de Linhares ${ }^{8}$, o agora deputado e ministro do Reino José Bonifácio de Andrada e Silva. Sua filiação à tradição do despotismo ilustrado, filtrada pelo liberalismo monarquiano, fica explícita quando, apesar de fazer o elogio de autocratas que haviam sido capazes de ilustrar e felicitar seus países, como Pedro o Grande e Frederico da Prússia, ele recomendava entretanto como adequadas às características do Brasil, as instituições do governo misto ou da monarquia temperada, que ele associava à Inglaterra (Andrada e Silva, 1998:174 e 247). Para ele, as oportunidades oferecidas pelo novo Império eram ilimitadas, dadas a vastidão de seu território e as inumeráveis riquezas nele disponíveis. No entanto, dividida horizontalmente pelas distâncias e verticalmente pela escravidão, a própria nação ainda estava por fazer. 
Cumpria, portanto, reduzir as primeiras e amalgamar as etnias, para que daí saísse "um todo homogêneo e compacto" (idem:49). Da mesma forma, era preciso abrir estradas, atrair a imigração estrangeira para ocupar o país, desenvolver a agricultura pelo uso racional do solo, civilizar os índios, distribuir terras - enfim, prover ao que lançasse as bases de uma nação próspera e poderosa. As receitas desse bom Estado seriam poucas, mas eficazes: leis, igualdade de tratamento, burocracia meritocrática, liberdade de imprensa, direitos individuais. Tudo isso era possível na medida em que o Estado ilustrado possuía um poder demiúrgico de criação: desde que com prudência, mas com pulso firme e celeridade na execução, "o legislador, como o escultor faz de pedaços de pedra estátuas, faz de bruto homens" (idem:174 e 307). Entretanto, José Bonifácio entendia que a conjuntura no início da década de 1820, com suas graves divisões dentro e fora do corpo político apresentava extraordinárias dificuldades a esse projeto de construção nacional. $\mathrm{O}$ papel civilizador da monarquia constitucional somente poderia cumprir seu destino caso a força e a habilidade de estadistas ilustrados fossem capazes de conjurar semelhantes perigos ao bem comum. Caberia, portanto, a um "hábil e enérgico ministério" (no fundo, o próprio) proclamar "ao povo, com eloqüência, a verdade e a razão - linguagem de sã política que convém a um governo forte e justo", e "paralisar os partidos e vigiar os planos e astúcias secretas" (idem:213-239).

“É bom entregar o princípio de um negócio de ponderação a Argos de cem olhos e o fim a Briareu ${ }^{9}$ de cem mãos. Na execução, não há segredo comparável à celeridade. Nos negócios, das três partes que são: a preparação, o exame e a execução; só a do meio deve ser obra de vários; o resto, de um só" (idem:198).

Foi nesse contexto de perigos à construção nacional que o projeto político coimbrão veio, por afinidade e contingência, se exprimir na linguagem constitucional dos monarquianos franceses. O intuito de José Bonifácio era chegar ao constitucionalismo liberal, contornando porém a estrada que conduzia os governos fracos à anarquia e à revolução. Isso seria possível desde que se combinassem os direitos fundamentais e a soberania nacional do modelo constitucional de 1791 com o Executivo forte da Carta francesa outorgada por Luís XVIII, em 1814. Mas, para tanto, era preciso ser realista. "Nos dois extremos", disse Maciel da Costa, "antes a tacha de apaixonado por antigas instituições, que não forem incompatíveis com a liberdade que todos desejamos, do que a de inovador temerário e demagogo; que entre um respeito su- 
persticioso e idólatra por antigas instituições e um furor temerário de inovações há um meio; este é o da circunspecção e da prudência" (AACB, 1823, III:94).

\section{O DISCURSO DO MONARQUIANISMO APLICADO: A BATALHA EM TORNO DA REPRESENTAÇÃO DA SOBERANIA NACIONAL NA CONSTITUINTE DE 1823}

O desafio de obter a adesão do auditório brasileiro por meio do discurso monarquiano apresentava, porém, aos coimbrãos vantagens sobre seus predecessores de 1789. A primeira era a possibilidade de explorar aos fracassos dos modelos subseqüentes de monarquia republicana (1791) e de república jacobina (1793). Foi o que fez Dom Pedro I na Fala do Trono com que abriu os trabalhos da Constituinte. A experiência daqueles modelos "inteiramente teoréticos e inexeqüíveis", levando à "anarquia de muitos" e, depois, ao "despotismo de um só", responsáveis pelas guerras civis e golpes de Estado na França e na Espanha, assim como pelo banho de sangue em que estava mergulhada a América hispânica, teria definitivamente comprovado que apenas um sistema constitucional realista seria capaz de assegurar a viabilidade do novo império. Era preciso, portanto, que o Brasil adotasse uma constituição "sobre bases sólidas, cuja sabedoria dos séculos testemunharam a verdade, para dar aos povos uma justa liberdade, e ao poder executivo, toda a força de que ele precisa" (AACB, 1823, I:16). Com referência a essa passagem da Fala do Trono, discursou José Bonifácio no dia seguinte:

“Eu não acho nas palavras do Imperador senão nossas próprias expressões e a vontade geral do leal povo do Brasil. Que quer esse povo? E para que tem trabalhado até agora tanto o governo? Para centralizar a união e prevenir as desordens que procedem de princípios revoltosos anarquia. O povo do Brasil, Sr. Presidente, quer uma constituição, mas não quer demagogia e anarquia [...]. Que quadro nos apresenta a desgraçada América! Há 14 anos que se dilaceram os povos, que, tendo saído de um governo monárquico, pretendem estabelecer uma licenciosa liberdade; e depois de terem nadado em sangue, não são mais que vítimas da desordem, da pobreza e da miséria [...] Vimos os horrores da França; as suas constituições apenas feitas, logo destruídas, e por fim um Bourbon, que os franceses tinham excluído do trono e até execrado, trazer-lhes a paz e a concórdia! [...]" (idem:26). 
Uma segunda vantagem estava no fato de que a independência política permitia argumentar que a tarefa a qual estava colocada envolvia a fundação de uma monarquia nova em um país novo - e não o remanejamento da Coroa bragantina no território de sua antiga colônia. Na França, os monarquianos haviam argumentado que a monarquia já existia antes da reunião dos Estados Gerais e que a vontade de mantê-la forte havia sido expressa pela nação nas consultas que haviam precedido aquele congresso. Esses fatos teriam erguido a Coroa à co-titularidade da representação soberana, justificando a preservação das prerrogativas régias de convocação, adiamento, prorrogação e dissolução do corpo legislativo (Furet e Halévi, 1996). Esse argumento se revelou, porém, ineficaz na medida em que a Assembléia Constituinte surgira de um golpe parlamentar imprevisto pelo povo e dirigido contra um monarca expropriado de sua soberania. Além disso, o tradicionalismo institucional da Coroa tornava-a indissociável do Antigo Regime, e todas as precauções para evitar seu excesso de poder sempre foram consideradas poucas pela Constituinte. Por outro lado, a partir do momento em que Dom Pedro se proclamara constitucional e ficaram claras as pretensões recolonizadoras das Cortes lisboetas, a imagem do Antigo Regime luso-brasileiro ficava associada à Europa - e, em particular, a um Portugal velho, pequeno e decadente. O novo império americano não se confundia com a antiga monarquia lusitana; era uma nação nova sobre um mundo também novo. Os contratempos dos monarquianos franceses pareciam assim se dissipar no Brasil.

Um terceiro ponto concerne ao fato de que essa mesma modernidade do Império servia também para legitimar a precedência institucional do Imperador a partir do próprio princípio da soberania nacional. A fim de se prevenir contra uma eventual maioria do grupo de Ledo na Assembléia, Andrada e Silva foi o primeiro a sustentar que a nova Coroa brasileira, com todas as prerrogativas decorrentes da vigilância suprema dos interesses nacionais, era um produto da vontade manifestada diretamente pelo próprio país (Monteiro, 1981:692). A oferta e aceitação por Dom Pedro do título de Defensor Perpétuo do Brasil, feita em nome de toda a nação pela Câmara Municipal do Rio de Janeiro, bem como sua posterior aclamação pública como Imperador Constitucional, em outubro de 1822, teriam cumprido a mesma função de legitimação democrática da realeza que, nos discursos monarquiano de 1789 e bonapartista de 1804, haviam sido exercidas pelos cahiers de dóleance que precederam os Estados Gerais e pelo referendo que havia instaura- 
do o regime cesarista. Essa manifestação verdadeiramente napoleôni$\mathrm{Ca}^{10} \mathrm{da}$ vontade soberana de fazer do príncipe seu primeiro representante teria sido reiterada e tornado, assim, perfeita e acabada com a cerimônia de sagração e coroação do Imperador, no início de dezembro de 1822. Ao se reunir a Assembléia em maio do ano seguinte, os constituintes achavam-se diante de um fato consumado, com que tinham de se conformar. Ela não poderia ser considerada Constituinte no sentido conferido por Sièyes, isto é, de uma representação soberana, porque a vontade do povo havia sido transmitida prévia e diretamente ao príncipe, que era seu interlocutor privilegiado. Os deputados deveriam se limitar a legislar sobre assuntos urgentes, reduzir a termo o pacto celebrado entre o príncipe e a nação - que definira a priori as prerrogativas da Coroa -, estabelecer o rol dos direitos fundamentais e organizar os demais poderes políticos, como o Legislativo e o Judiciário. Qualquer tentativa em contrário, isto é, de reduzir a autoridade monárquica aos limites do modelo de 1791, importaria em uma traição dos deputados ao juramento prestado na posse, ocasião em que se haviam comprometido a guardar fidelidade à vontade nacional.

Daí porque, no juramento da coroação e no discurso com que abriu a Constituinte, Dom Pedro sustentou que defenderia a futura constituição desde que ela fosse digna dele e do Brasil. Embora a expressão fosse emprestada de Luís XVIII (Rosanvallon, 1994:250), ele queria dizer que tinha sobre o projeto de constituição um poder de veto que se fundava não no direito divino do absolutismo, como sempre se pensou, mas no fato de ter sido constituído pela nação o defensor primeiro e perpétuo de seus interesses. Nessa posição, caso o julgasse contrário à vontade ou ao bem-estar do povo, Dom Pedro estaria obrigado a se opor ao projeto, tendo o poder de vetá-lo, dissolver a Assembléia e convocar uma nova. Esse argumento, apresentado na Assembléia por Antônio Carlos de Andrada Machado - "O poder monárquico, despojado das atribuições que já a nação lhe concedera e que o nosso ciúme lhe arranca, tem seu sem dúvida direito de recorrer à nação [...]" (AACB, 1823:99)-, correspondia, sem tirar nem pôr, àquele desenvolvido por Malouet em 1789, para justificar o direito de veto de Luís XVI sobre o projeto da Constituinte francesa.

“Um monarca não tem nem o direito nem o poder de impedir um povo que quer uma constituição de fazê-la. Ele não tem direito de veto, nem de obstar à uma constituição pedida pela Nação. Entretanto, se aconte- 
cer que os representantes adotem uma, que seja evidentemente contrária à vontade e ao interesse geral, não duvidaríamos que nesse caso o chefe da Nação tem o direito de suspender tal constituição, apelar ao povo e lhe pedir que manifeste sua vontade expressa por meio de novos representantes" (Malouet, 1996:368).

Essa linha bastante sofisticada de argumentação que, ao legitimar o poder monárquico como interlocutor privilegiado da vontade da nação, tornava desnecessário recorrer às fundamentações contra-revolucionárias de De Bonald ou De Maistre, então em voga na Europa, não pode portanto ser compreendido fora desse contexto meta ou semiconstitucional no qual a luta política se desenrolava em 1823. Então muito difundido na Espanha e em Portugal, o costume de jurar respeito a constituições ainda por fazer, de adotar as de outros países ou ainda de jurar as bases de umas e outras induzia à idéia generalizada de que era possível a existência de um "estado de constitucionalidade" mesmo que ela ainda não constasse de um documento escrito. Como conseqüência dessa concepção pré-positivista e jusnaturalista que animava o debate político, a Constituição era também entendida como um conjunto de princípios abstratos que legitimamente organizavam a sociedade política - soberania nacional, representação política, separação dos poderes e direitos fundamentais. Em 1823, portanto, embora ainda sem Constituição escrita, o Brasil seria um Estado constitucional - e tanto assim que, desde a aclamação, o título do Dom Pedro era oficialmente o de "Imperador Constitucional". O problema é que governo e oposição não estavam de acordo quanto às "bases" sobre as quais essa constitucionalidade do país em tese repousaria. Ambos se disputavam, desde a abertura da Constituinte, não tanto em torno do estado de coisas a ser criado pela futura constituição, mas da interpretação dos acontecimentos relativos e posteriores ao Fico e da maneira como eles teriam determinado a forma de representação política do soberano. Os princípios positivos que norteariam a constituição só poderiam ser deduzidos assim depois de resolvida a questão referente à primazia de uma das duas instituições, Coroa e Assembléia, o que teria lugar quando se reconhecesse ou se rejeitasse o direito de veto e de dissolução reivindicados pelo imperador.

Até que tal ocorresse, haveria indeterminação e luta. Na véspera da abertura da Constituinte, o irmão de José Bonifácio, Antônio Carlos de Andrada Machado (como ele, também deputado e ministro), dera já em plenário o tom da defesa das prerrogativas da Coroa: 


\section{Christian Edward Cyril Lynch}

“Cuidará que a assembléia é soberana e soberana do imperador? Se o pensa, saiba que poderes delegados e independentes não podem ser senão iguais, e que um poder como o do imperador, que igual como executor, exerceu sobre nós superioridade, como o convocar-nos, e que por necessidade há de influir sobre os poderes delegados todos, visto ser essa influência da essência da monarquia constitucional, não é nem pode ser olhado senão como superior. Talvez venha o nobre preopinante com a arenga de assembléia constituinte que em si concentra os poderes todos; advirta porém que não podemos concentrar poderes que existiam antes de nós, e dimanaram da mesma origem, e não foram destruídos pelo ato de nossa delegação; antes tiveram a principal parte na nossa criação. A nossa procuração é coarctada: ampliá-la seria usurpação; e a esta me oporei eu sempre" (AACB, 1823,I:11).

A lição foi repetida dois dias depois, na discussão de resposta à Fala do Trono:

“A nação, Sr. Presidente, elegeu um imperador constitucional, deu-lhe o poder executivo, e o declarou chefe hereditário; nisto não podemos nós bulir; o que nos pertence é estabelecer as relações entre os poderes, de forma porém que se não ataque a realeza; se o fizermos, será a nossa obra digna do imperador, digna do Brasil e da assembléia" (idem:25).

A 26 de junho, José Joaquim Carneiro de Campos explicitou os fundamentos daqueles que, como ele, defendiam a Coroa. Depois de aplicar ao Brasil o tropos de Mirabeau e Mounier, referido no início deste artigo, de que nosso povo não seria composto de selvagens que vinham nus para formar uma sociedade, já tendo sido previamente "ajustado e firmado o nosso pacto social", e bastando apenas "especificar as condições indispensáveis para fazer aquele pacto profícuo, estável e firme" (AACB, 1823, II:126), ele adicionou:

"A soberania é inalienável; a nação só delega o exercício de seus poderes soberanos. Ela nos delegou somente o exercício do poder legislativo, e nos encarregou de formarmos a constituição de um governo por ela já escolhido e determinado; pois muito antes de nos eleger para seus representantes, tinha já decretado que seria monárquico, constitucional e representativo. Ela já tinha nomeado o Sr. Dom Pedro de Alcântara seu supremo chefe, seu monarca, com o título de Imperador e Defensor Perpétuo. Estas bases jamais podem ser alteradas pela constituição 
que fizermos ou por qualquer decreto ou resolução desta assembléia [...]" (idem:127).

A conseqüência dessa divergência foi que as relações entre os dois poderes, "constituídos" sem prévia constituição, passariam a se desenvolver em um quadro obscuro de competências, definida por "bases" em torno das quais não havia consenso. $O$ fato de a Constituinte passar a acumular também o Poder Legislativo ordinário, até então exercido pela Coroa, fragmentando o poder político em um momento em que a guerra contra Portugal, a necessidade de reconhecimento do Império e a construção do Estado recomendavam, ao contrário, a concentração desse poder, não tornavam mais fáceis a convivência entre as duas instituições. O diagnóstico da elite coimbrã era o de que, justamente nessa situação de urgência e gravidade, que exigia "energia" redobrada do Poder Executivo, este estava, ao contrário, cada vez mais dependente de uma assembléia cujos membros subordinavam suas idéias e posições políticas à ambição de pastas ministeriais e investimentos em suas províncias de origem. Por outro lado, apegada prioritariamente às suas províncias, a maioria aspirava à descentralização, tolerando a continuidade do regime centralizado siet in quantum expediente necessário, mas transitório, à manutenção de uma ordem pública que as localidades não tinham ainda como prover sozinhas - daí porque tentavam transigir com o governismo coimbrão. Essa transigência, porém, era instável, e o governo nunca pôde dispor de maioria consolidada. Se por fim acabasse por prevalecer o entendimento de que a Assembléia era soberana diante do Imperador, pensaram os governistas, as competências dele seriam arrancadas uma a uma, esvaindo-se toda e qualquer esperança de controle do processo político e, por conseguinte, de estabilidade institucional. Convencer então a maioria da assembléia de que as bases constitucionais que pautavam a relação entre os dois poderes correspondiam às do projeto monarquiano de 1789 , e não à monarquia republicana de 1791, pareceu aos membros da elite coimbrã o único meio de impedir o colapso das novas instituições monárquicas e, com elas, o projeto de construção nacional baseado na ordem e na unidade do Império.

Argumentos puramente monarquianos, porém, talvez fossem insuficientes para convencer a Assembléia Constituinte-como todas elas, ciosa de seu mando. Foi nesse contexto estratégico que, logo em seus primeiros dias, começou a ser mobilizado o conceito de Poder Moderador. 


\section{NEUTRALIDADE ATIVA, DISCRICIONARIEDADE, CENTRALIZAÇÃO: 0 PODER MODERADOR COMO COLUNA MESTRA DA SOBERANIA NACIONAL}

Até a abertura da Constituinte, os coimbrãos exprimiram-se rigorosamente nos termos monarquianos, isto é, sustentando que o regime monárquico constitucional autêntico não era o da monarquia republicana de 1791, e sim o da Constituição inglesa conforme a leitura de Bolingbroke, isto é, um governo misto dotado de uma Coroa forte, que governava como Poder Executivo e que resolvia, por meio da prerrogativa do veto e da dissolução, os eventuais conflitos interinstitucionais ${ }^{11}$. Entretanto, foi nesse mesmo período que o conceito de Poder Moderador começou a ser empregado no meio brasileiro. Embora na origem remontasse, como vimos, ao sentido monarquiano que Saint-Pierre lhe conferiu no debate travado durante a Revolução, o conceito passara na Europa a ser genericamente associado à idéia de uma terceira força que, independentemente da natureza do regime, ficaria encarregada de manter a paz entre Executivo e Legislativo. Em 1823, o conteúdo semântico do conceito era aquele de Poder neutro, meramente arbitral, que lhe havia sido atribuído pela doutrina liberal de Benjamin Constant em 1814 e que se difundira no início do reinado de Luís XVIII, quando o próprio partido ultramonárquico $(u l t r a)$, então maioria parlamentar, o adotou para impor seus pontos de vista ao rei. Embora reintroduzido no contexto monárquico, seu significado era, pois, algo diverso daquele que lhe havia sido conferido 25 anos antes. Agora ficava reservado ao príncipe, autoridade inviolável, apenas o exercício da prerrogativa régia em casos de crise, para fins de controle estrutural da constitucionalidade, ficando ele afastado do governo, reservado a ministros que pudessem ser responsabilizados por seus atos. As duas intenções claras da doutrina eram: primeiro, a de empregar o prestígio e a neutralidade do rei para obter a efetividade e a estabilidade do regime constitucional, coisa que a França não havia conhecido até então; e segundo, a de prevenir uma política de retorno ao Antigo Regime, afastando o monarca dos negócios públicos. Eis como, em 1816, o Visconde de Chateaubriand qualificara o poder monárquico:

"A doutrina sobre a prerrogativa régia constitucional é: que nada proceda diretamente do rei nos atos do governo; que tudo seja obra do ministério, mesmo o que se faça em nome do rei e com sua assinatura, projetos de lei, decretos, escolha de homens. O rei, numa monarquia representativa, é uma divindade que nada pode atingir: inviolável e sagra- 
do, ela é ainda infalível; pois, se houver um erro, esse erro é do ministro e não do rei. Assim, pode-se tudo examinar, sem ferir a majestade real, pois tudo decorre de um ministério responsável" (Chateaubriand, 1987:172).

Depois de derrotado o partido ultramonárquico, os liberais retomaram a bandeira do Poder Moderador. Foi o que fez o Conde de Lanjuinais, em 1819, em Constituições da Nação Francesa, quando glosou a idéia de Constant:

"Para que haja uma liberdade regular, é necessário uma autoridade mediadora diretiva, moderadora, neutra a certos aspectos, absoluta em outras relações, enfim irresponsável, uma autoridade que previna ou termine toda luta perniciosa, que propicie ou restabeleça a harmonia necessária entre as grandes autoridades. Eis o que apenas o Rei pode fazer, propondo as leis, recusando ou concedendo sanção às resoluções das duas câmaras, nomeando os pares, e criando novos pares; convocando, adiando, ou dissolvendo as câmaras; usando de seu direito de agraciar e comutar as penas, nomeando e demitindo ministros; distribuindo, revogando as recompensas e os favores" (Lanjuinais, 1832:219).

Entre nós, tudo leva a crer que, diante da perspectiva de enfrentamento no terreno da "metaconstitucionalidade", os governistas brasileiros passaram a empunhar o estandarte ultraliberal do Poder Moderador para defender na Assembléia sua concepção monarquiana de Estado constitucional. A elite coimbrã estava consciente das dificuldades da obra de construção nacional que a independência impunha e da necessidade de uma Coroa forte para garanti-la, mas estava pessimista quanto à possibilidade de derrotar o modelo institucional de governo de Assembléia na Constituinte. Este acabara de triunfar em Portugal e havia sido defendido então por uma parcela significativa de deputados que, tendo abandonado as Cortes, haviam sido eleitos e ocupavam cadeiras na Constituinte brasileira, como Muniz Tavares, Araújo Lima, Lino Coutinho, Custódio Dias e Martiniano de Alencar, entre outros (Carvalho, 1979).

O fato de tratar-se o Poder Moderador de um slogan do partido ultraliberal não pareceu constranger os membros da elite coimbrã, até porque, da forma como era empregado, fazendo referências ao que havia de mais moderno na publicística francesa de então, tratava-se de um formidável artifício retórico de que os brasilienses, com seus fumos 
também ultraliberais, dificilmente conseguiriam se desembaraçar ${ }^{12}$. Foi antevendo, portanto, a resistência que enfrentaria a proposta institucional de corte monarquiano que os partidários do Imperador lançaram mão da teoria do poder neutro como forma de dourar a pílula. Embora isso pareça não fazer sentido, já que o Poder Moderador em princípio enfraqueceria o poder monárquico, o estratagema envolvia uma engenhosa linha de argumentação: o Poder Moderador era uma invenção da moderna escola francesa de direito público e, portanto, insuspeita aos brasilienses. Segundo tais autores, aquele poder, cujas atribuições compreendiam o direito de veto e o de dissolução era da essência de toda a monarquia constitucional (Constant, 1997:324). No Brasil, desde o 7 de setembro, já havia um Estado independente, e seu regime era o monárquico constitucional; portanto, esse Poder Moderador também já existia. Logo, o Imperador detinha suas atribuições, podendo vetar e dissolver a câmara. Estava armada, assim, a arapuca retórica.

Grosso modo, três foram as leituras ou visões do Poder Moderador enfatizadas durante a Constituinte de 1823, assim como três foram os deputados que as desenvolveram - Antônio Carlos de Andrada Machado, irmão de Andrada e Silva; José Joaquim Carneiro de Campos, futuro Marquês de Caravelas, e João Severiano Maciel da Costa, futuro Marquês de Queluz. Embora partilhassem da mesma formação jurídica coimbrã e tivessem mantido relações mais ou menos estreitas com o Conde de Linhares ${ }^{13}$, os matizes assimilados pelo conceito de Poder Moderador em seus discursos não apenas diferiam entre si como tal ocorria na proporção direta em que cada um deles se distancia da teoria de Benjamin Constant. Aquelas três visões foram: primeiro, o Poder Moderador como um lugar privilegiado do chefe do Estado, desinteressado e acima da "política"; segundo, como um poder de exceção a serviço da salvaguarda do sistema constitucional; e terceiro, como a razão da centralização político-administrativa.

Na primeira dessas visões (que era também a mais próxima de Cons$\left.\tan t^{14}\right)$, o Poder Moderador era apresentado menos como um poder político de conteúdo definido do que como um lugar privilegiado e inalcançável ocupado pelo chefe do Estado, cuja posição sublime imporia aos deputados preservá-lo de críticas e cercá-lo de um cerimonioso e contemplativo respeito. Ao enfatizar a necessária inviolabilidade da pessoa do monarca, por cujos erros responderiam os ministros, Andra- 
da Machado refletia os anseios mais imediatos do Imperador, que pretendia assim convencer a imprensa a poupá-lo de seus excessos ${ }^{15}$. $\mathrm{O}$ Imperador era "o poder influente e regulador, a coluna mestra da sociedade [...], superior a todos os outros poderes, a quem nenhuma das manifestações de submissão, de deferência e de respeito jamais podem ser degradantes" (AACB, 1823, I:2). Detendo o monopólio cognitivo do interesse público, "acima das nossas fraquezas e paixões" (idem:98), o monarca, esse verdadeiro "ser metafísico", o único capaz de "distinguir o verdadeiro interesse da sociedade e de se guiar por ele" (idem:3), estaria em condições ideais para governar e regular de maneira adequada o funcionamento dos demais poderes.

"Quando uma nação é regida por um só indivíduo, o governo desta nação é monárquico, se o poder é hereditário na dinastia reinante, e se o monarca tem alguma parte ao menos no supremo poder moderador nacional. Se todos os poderes se concentram num só homem, a monarquia é absoluta, a qual porém se difere do despotismo em ser o poder exercitado segundo leis fixas [...]. Se os poderes são divididos, ficando a legislação na mão dos representantes nacionais, e o poder executivo na mão de um monarca hereditário, inviolável e com alguma influência sobre os outros poderes, temos o que chamamos monarquia constitucional representativa" $\left(\right.$ idem:26) ${ }^{16}$.

O que se percebe é que, enquanto Constant, Chateaubriand e Lanjuinais, contemporâneos de Andrada Machado, brindavam Luís XVIII com semelhante palavrório para compensá-lo da perda que lhe queriam impor do Poder Executivo, Antônio Carlos invocava-as para convencer o auditório local de que o poder do príncipe deveria ser mantido. Bom conhecedor de retórica, plenamente ciente do poder do argumento de autoridade em um país periférico, Andrada Machado ressaltava o intrínseco caráter moderno do Poder Moderador, que conheceria perfeitamente por ser recém-chegado das Cortes lisboetas. Mobilizando assim seu contato íntimo e com as últimas descobertas da modernidade política européia, Antônio Carlos declarava sem rebuços que um deputado que desconhecia ou negava o caráter de centralidade do Poder Moderador numa monarquia constitucional confessava sua ignorância do funcionamento de próprio sistema representativo. Os adversários que não se submetessem ao argumento de autoridade ficavam assim advertidos do ridículo em que poderiam incorrer diante de todo o país representado na Assembléia. 
No entanto, a compreensão ampla da natureza e da importância do Poder Moderador no conjunto de peças do governo representativo ficaria patente na formidável defesa que lhe fez Carneiro de Campos, quando o apresentou, dentro de uma teoria mais ampla do governo representativo, como um controle político-estrutural, um poder de exceção a serviço da salvaguarda do sistema constitucional. O governo representativo, explicava ele, era um meio termo entre a democracia e a monarquia absoluta. Na primeira, a influência nacional, sendo tudo, faria do chefe uma figura nula, ao passo que na segunda tal proporção de todo se inverteria. O governo representativo, por sua vez, caracterizar-se-ia pela influência moderada e indireta que a nação tinha sobre o governo. Duas eram as suas espécies: a república e a monarquia temperada. Em uma evidente alusão ao modelo de 1791, ele entendia que, para que o governo fosse republicano, seria "indispensável que a preponderância se conserve sempre fixa no corpo que representa a massa social, e por conseqüência que o chefe da nação não possa suspender o efeito da lei, (não) seja um mero executor delas". Nesse caso, ainda que houvesse uma personalidade com o título de imperador ou rei, não haveria monarquia, e sim república, pois que ele "não será mais que um arconte, cônsul ou doge, um mero executor de leis" ${ }^{17}$. Por outro lado, a monarquia representativa tinha lugar "se o corpo dos representantes perde[sse] essa preponderância, e a sua influência na formação das leis se repart[isse] com igualdade entre ele e o chefe da nação" (AACB, 1823, II:128). Essa influência que o príncipe exerceria sobre o Legislativo se traduzia pelo direito de veto, direito tanto mais necessário porque, além do Executivo, o monarca...

“tem também o caráter augusto de Defensor da Nação. Ele é sua primeira autoridade vigilante, guardião de nossos direitos e da Constituição. Esta suprema autoridade faz dele um ser sagrado e inviolável, reconhecido pelos mais sábios publicistas de nosso tempo como um poder distinto do Executivo, por causa de sua natureza, finalidade e competências. Essa suprema autoridade, dizia eu, chamada poder neutro, moderador ou tribunício, é essencial aos 'regimes representativos', desde que era a garantia de que os mandatários do povo jamais se arrogariam em 'senhores e tiranos'. Diante da possibilidade de contradição desses mandatários, relativamente à vontade e ao interesse geral, é preciso que a Nação arme de poderes aquele que é superior a todas as considerações e interesses particulares, o único a ter um interesse eminente na manu- 
tenção da constituição, para que ele vele por ela como seu guardião" (ibidem).

Por conseguinte, o Poder Moderador de Carneiro de Campos não derivava simplesmente uma qualidade da realeza ou da natureza das coisas, como no discurso de Andrada Machado; ele era, no melhor estilo monarquiano, o direito da nação de ser protegida pelo representante do bem comum quando ela estivesse desprovida de meios eficazes de autodefesa contra o particularismo dos interesses legislativos; a autoridade neutra capaz de manter in extremis a ordem constitucional, a bem da unidade da vontade nacional, contra as veleidades facciosas e particularistas de seus representantes eleitos. Não sendo possível, explicava, que o povo soberano agisse por conta própria para fazer valer seus interesses por si mesmo - pois que "os trabalhos a que a maioria se dedica e a falta de tempo e de meios para se entregar a meditações mais profundas o obrigam a se conduzir quase sempre por sensações" (DACB , 1823, II:468) -, o fato do sistema representativo impunha a existência e a delegação daquele poder que, "como atalaia da liberdade e dos direitos do povo, inspeciona e equilibra todos os outros poderes" (AACB, 1823, II:129). Tendo esse poder sido delegado por aclamação popular ao Imperador, este se tornara a "suprema autoridade vigilante" da nação, cuja missão era "impedir a perturbação da ordem pública e o desfuncionamento da máquina política" (DACB, 1823, II:468). "Remédio extremo e instância última do sistema constitucional", o Poder Moderador deveria ser aplicado quando não houvesse "outro meio ordinário e pacífico de evitar danos iminentes ao Estado" (AACB, 1823, II:109-110). O Poder Moderador de Caravelas era, portanto, um poder discricionário emergencialmente exercido pelo chefe do Executivo para salvar o regime representativo nascente do perigo de desagregação do corpo político; uma espécie de freio de mão leviatânico para as emergências de um Estado liberal incipiente e frágil, despido de tradições e por isso ameaçado pelo seu próprio déficit de legitimidade - um sucedâneo aperfeiçoado, como seu irmão reconheceria depois, da ditadura romana.

"É verdade que a nossa constituição foi a primeira que levou esta doutrina a efeito e à prática, porque criou explicitamente o poder moderador, e não vejo isto nas outras constituições; mas isto é um grande merecimento da nossa constituição, pois que tem aperfeiçoado assim os princípios dos governos livres [...]. Este poder veio fazer uma exceção à essa regra [da referenda ministeria] nos poucos atos próprios do dito 
poder, e isto para remediar as faltas das antigas ditaduras. O poder moderador não é senão uma espécie de ditadura, ditadura, porém, restringida a certos e poucos objetos, a certos e determinados atos particulares" (AS, 1841, III:207-208).

A última das leituras do Poder Moderador - a de João Severiano Maciel da Costa - é a que mais se afasta da concepção original de Constant. Ele critica inicialmente a experiência francesa do senado napoleônico, a quem a constituição consular atribuíra o dever de salvaguardá-la. Esse retumbante fracasso comprovara que tal papel não deveria ser desempenhado por um colegiado, mas pela única pessoa do Imperador. Tal como nas outras duas leituras, Maciel da Costa repetia que, além do poder de executar as leis, o monarca tinha "o supremo poder moderador" em virtude do qual "ele vigia como atalaia sobre todo o Império; é a sentinela permanente, que não dorme, não descansa". Para qualificar o papel do monarca no exercício deste último, o futuro Marquês de Queluz invocava uma imagem muito comum no debate político da época, associando-o à mesma figura mitológica a que recorria José Bonifácio: o príncipe era "o Argos político, que com cem olhos tudo vigia, tudo observa". Maciel da Costa ia, porém, além de seus antecessores ao conferir ao Estado, personificado no monarca, o grau de um verdadeiro representante existencial da soberania nacional. É o que fazia ao afirmar que, com sua centena de olhos, ele "tudo toca, tudo move, tudo dirige, tudo concerta, tudo compõe, fazendo aquilo que a Nação faria se pudesse". Para que a Coroa pudesse, porém, se desempenhar a contento de suas tarefas, exercendo aquela vigilância que lhe fazia o apanágio em um país vasto como o Brasil, ela carecia de meios administrativos que lhe dessem "olhos e braços por todo o Império" (AACB, 1823, $\mathrm{V}: 164)$. Ao contrário do que ocorria nos Estados Unidos, para tanto não bastaria que se atribuísse ao Poder Judiciário tal papel, porque também ele, na qualidade de emanação indireta da soberania nacional representada pelo Imperador, deveria estar sujeito àquela vigilância.

"Esses olhos, esses braços, são as autoridades provinciais, que vêem e tocam por ele e com ele estão em contínuo contato; relações estas que não quadram aos membros do poder judiciário, que deve ele mesmo ser vigiado, sobreroldado [...]. Não há, senhores, outro meio nenhum de governar um grande país: dividir a guarda e a vigia da observância das leis por tantas autoridades subalternas, quanto bastem para o feliz desempenho; premiar os zelosos e exatos; punir os infiéis e negligentes" (ibidem). 
Era dessa forma que o futuro Marquês de Queluz invocava o Poder Moderador para justificar a centralização político-administrativa, contra as pretensões de autonomia das províncias e - ça va sans dire contra a própria opinião de Constant, ele mesmo descentralizador moderado (Constant, 1997:423).

Registre-se, porém, que os monarquianos brasileiros não falaram para um auditório passivo. A doutrina da paridade ou precedência do Imperador diante da assembléia foi contestada várias vezes pela oposição, que argumentava com a teoria do poder constituinte de Sièyes ${ }^{18}$. Além dessa rejeição mais geral da teoria "meta-constitucional" monarquiana, um membro da oposição, o deputado pernambucano Francisco de Paula de Almeida e Albuquerque, inteligentemente refutou também o argumento do Poder Moderador desenvolvido pelo governo. Embora, citando Malouet, reconhecesse que "o chefe da nação é o guarda nato da felicidade geral, é aquele a quem pertence vigiar sobre todos os outros poderes", devendo, portanto, ter o direito de veto sobre os projetos de lei, esse veto somente aproveitaria ao Imperador depois da Constituição elaborada e promulgada pela Constituinte, pois era ela que deveria fixar como e quando caberia ao monarca o exercício dessas prerrogativas (AACB, 1823, II:124). Foi o deputado Henrique de Resende, todavia, quem com mais veemência combateu os argumentos de Carneiro de Campos, valendo-se de argumentos semelhantes àqueles com que Sièyes combatera o veto absoluto proposto pelos monarquianos:

“Dizem que a assembléia não é infalível e é sujeita às paixões. E o Imperador é um anjo, não tem paixões? O Imperador é mais sujeito a essas paixões, porque tem para elas mais incentivos: comanda a força, dá os empregos, as honras e é quem executa as leis; por isso tem mais interesse em que elas sejam a seu jeito. Nós nada disso temos e somos temporários; tornamos para o que antes éramos. A assembléia não é infalível, e o Imperador é? Nego. É tanto homem como nós, e ademais tem maiores entraves para ver a verdade, mais incentivo às paixões. Quando os povos nos mandaram aqui para fazer a constituição e as reformas indispensáveis, estavam convencidos que essa constituição essas reformas eram necessárias e sabiam quais eram elas. Viemos com plenos poderes; a constituição e as reformas devem ser efetivas e de nenhuma forma devem depender da sanção imperial os decretos da assembléia constituinte" (idem:130). 
De uma forma geral, porém, nenhum deputado atacou diretamente o Poder Moderador como instrumento do despotismo - ao contrário, evitaram cuidadosamente combatê-lo de frente. Isso não quer dizer, contudo, que os adversários do ministério não pudessem adivinhar o cavalo de Tróia, como de fato o fizeram; significa apenas que eles encontraram muitas dificuldades para fundamentar, de forma adequada, o argumento de que, embora ultraconstitucional, a teoria do poder neutro estava sendo mobilizada para fins contrários àquilo que eles, "brasilienses", percebiam como verdadeiramente constitucional. Tanto assim foi que, no frigir dos ovos, ele não foi incorporado ao anteprojeto por Andrada Machado, a essa altura já na oposição. Ele já sabia bem o que significava para o governo a concessão desse poder e, por isso, não concedeu ao Executivo a faculdade específica de dissolver a Câmara de Deputados - o mais importante de todos os mecanismos moderadores.

* * *

É conhecido o desenrolar factual dessa história, com o fracasso dos governistas brasileiros em evitar, ao menos pelo verbo, a apropriação integral da soberania pela Assembléia. Depois da queda dos irmãos Andrada e de sua passagem à oposição, cindindo a elite coimbrã, o Imperador e seus defensores foram, primeiro, derrotados na batalha em que pretendiam limitar os poderes constituintes da Assembléia. Os governistas também não conseguiram depois convencer a maioria a conceder ao Imperador o direito de pelo menos vetar a legislação ordinária. Mais adiante, foi o anteprojeto apresentado ao plenário que excluiu o direito de dissolução da câmara das atribuições imperiais. $\mathrm{O}$ derradeiro fracasso verificou-se na tentativa de se pôr um paradeiro na crescente atividade legiferante ordinária, às expensas dos debates estritamente constitucionais, os quais ficaram em segundo plano ${ }^{19}$. No penúltimo mês de seu funcionamento, depois de discutidos apenas os doze primeiros artigos, a maioria da assembléia decidiu paralisar toda a discussão sobre a constituição para se dedicar exclusivamente aos assuntos do governo, dando assim sinais inequívocos de pretender derrubar o ministério de Carneiro de Campos e encurralar o Imperador. Por fim, o episódio do "brasileiro resoluto", em novembro, deu ensejo a que a assembléia começasse a apresentar cenas que, aos olhos de muitos contemporâneos, deviam ter evocado as da Revolução francesa, com os deputados convidando o povo a ocupar o plenário e fazendo discursos inflamados de ódio aos supostos inimigos da pátria: eram os 
episódios de 1791, replicados em Cádiz e em Lisboa, que agora iriam se repetir no Rio. Os governistas aconselharam então o Imperador, na qualidade de Defensor Perpétuo do Brasil, e em conformidade com a teoria monarquiana, a dissolver a assembléia manu militari. $\mathrm{O}$ conselho fora dado pelos próprios Andradas, quando na situação (Monteiro, 1981:784), mas dessa vez Dom Pedro o seguiu. Pondo em risco o país, ao se dividirem em facções e se deixarem arrastar por elas, os deputados constituintes teriam perjurado o compromisso de defender a integridade do Império, sua independência e à dinastia. Vez que "males extraordinários exigem medidas extraordinárias", a dissolução justificava-se como uma medida de salvação pública (Javari, 1993:83).

Embora houvesse quem, afinado com a teoria ministerialista, defendesse a legitimidade do ato do imperador sob o argumento de que a dissolução era atribuição natural de um monarca constitucional (Lustosa, 2000:409), o fato é que, ciente da má impressão que o ato provocaria nas províncias e objetivando convencer o público de sua constitucionalidade, Dom Pedro fez o decreto de dissolução vir acompanhado da promessa de uma nova constituinte, que por sua vez trabalharia sobre um projeto "duplicadamente mais liberal" que o produzido pela Assembléia (Javari, 1993:81). Tomando este último por base, o novo anteprojeto foi elaborado por Dom Pedro e por seus novos conselheiros de Estado, entre os quais estavam Maciel da Costa e Carneiro de Campos, a quem a literatura tradicionalmente atribui a autoria do projeto final (Lira, 1979:75). Este foi enviado para exame das câmaras municipais do país, as quais o aprovaram praticamente sem objeções ${ }^{20}$. Por fim, o Senado da Câmara do Rio de Janeiro - o mesmo que, dois anos antes, oferecera a Dom Pedro o título de "Defensor Perpétuo" - fez requerer ao governo que se dispensasse a formalidade de uma nova constituinte e se jurasse de vez o projeto, o que veio a ocorrer ${ }^{21}$. Assim triunfava, embora pela força - mas uma força para eles absolutamente legítima -, a pretensão monarquiana de fundar a autoridade principesca diretamente sobre a soberania nacional que a aclamara. Tal como Napoleão Bonaparte havia governado pela "graça de Deus", mas também "das Constituições" (Rials, 2002:44), a dinastia de Bragança também passava oficialmente a imperar, no Brasil pela "unânime aclamação dos povos". Se por um lado os argumentos mobilizados na arena política haviam sido extraídos, como de fato foram, do discurso monarquiano francês, por outro, o seu fracasso no país de origem e o êxito com que foi aqui adotado abriram possibilidades inéditas de verifica- 
ção empírica de seu desempenho institucional, o que na Europa ainda não havia acontecido.

\section{ENTRE A FIDELIDADE JURÍDICA E A INFIDELIDADE POLÍTICA: AS AMBIGÜIDADES DO NOVO TEXTO CONSTITUCIONAL}

Comparadas às suas congêneres, a Constituição de 25 de março de 1824 era provavelmente a carta monárquico-constitucional mais liberal de seu tempo (Carvalho, 1993:25). Espanha e Portugal já haviam a essa altura retornado ao absolutismo, ao passo que a França era regida por uma Carta mais concisa, mas também mais vaga, cuja fonte de legitimidade não se achava na nação, mas nos desígnios da divina Providência (Rosanvallon, 1994). Em contraste, a Constituição de 1824 estava, na sua maior parte, em consonância com o espírito de suas malogradas predecessoras ibéricas: ela consagrava a soberania nacional (art. 12), a divisão de poderes, o bicameralismo, a responsabilidade ministerial, o sistema representativo a censo baixo e amplo e uma extensa declaração de direitos fundamentais. Por outro lado, a influência monarquiana fez-se sentir em pontos centrais do funcionamento do regime, que derivavam do modo como o conceito de Poder Moderador havia sido recepcionado.

A quase unanimidade da historiografia brasileira partilha de opinião de que essa recepção se fez de forma a desfigurar a doutrina de Constant, evidência da pretensão absolutista de seus agentes (Carneiro da Cunha, 1985:256; Bonavides e Andrade, 1991:96; Fausto, 1999:152; Faoro, 1997:290). A Constituição teria atribuído o exercício do Executivo e do Moderador ao monarca, quando a intenção de Constant era a de separá-los para consagrar o parlamentarismo como sistema de governo. No entanto, a questão é mais complexa e sutil. Antes de tudo, é preciso separar dois aspectos distintos da transposição: o jurídico - a forma como as competências preconizadas por Constant foram incorporadas pelos autores da Constituição; e o político - os objetivos que a Coroa perseguia com a recepção do conceito. Essa distinção é fundamental na medida em que as intenções dos atores são mais voláteis, mudando conforme a composição de interesses, ao passo que a finalidade das instituições constitucionais é a de estabelecer regras fixas para estabilizar o jogo político. Embora seja correto afirmar que o direito preserva certa margem de discricionariedade decisória no interior do procedimento hermenêutico a que suas normas se sujeitam ao serem aplicadas, tal não elide o fato de que mesmo assim permanecem limites con- 
sideráveis a uma ação política puramente discricionária. A despeito disso, o que se verifica entretanto é que os especialistas geralmente não levam na devida consideração a relativa autonomia dos campos quando, ao contrário, o seu pressuposto era uma das mais importantes pedras de toque do constitucionalismo oitocentista. A tarefa de identificar as matrizes ideológicas de um texto constitucional implica a localização dos conceitos que o informam e sua identificação com os tipos de discursos políticos a que originariamente pertenciam, dentro das possibilidades que os agentes constitucionais tinham de conhecê-los. No caso concreto, penso que um bom ponto de partida passaria por, primeiro, examinar os textos constitucionais das demais nações da época; segundo, tentar apreender o que se entendia então por governo parlamentar; e terceiro, medir o grau de conhecimento que o meio político brasileiro possuía acerca da obra de Constant e verificar se houve alterações na atribuição das competências do Poder Moderador. À luz dessas questões, torna-se possível opor pelo menos três objeções ao argumento de que, por não haver consagrado o parlamentarismo inglês, a Constituição de 1824 teria traído a doutrina de Constant para operar uma verdadeira "constitucionalização do absolutismo" (Bonavides e Andrade, 1991:96).

A primeira dessas objeções consiste no fato de que todas as constituições do século XIX, inclusive as ibéricas, designavam o rei como titular do Executivo. Durante os Cem Dias, quando teve a oportunidade de redigir uma constituição liberal para Napoleão, o próprio Constant esquivou-se de se exprimir em termos de separação entre executivo e moderador para evitar a suscetibilidade dos atores envolvidos. Ele propositadamente preferiu expressões mais imprecisas, como "Imperador, governo, ministros e câmaras" (Rials, 2002:45), certo de que, deixando o texto mais flexível e mais aberto a interpretações, com o tempo haveria de se formar um consenso em torno do espírito doutrinário liberal dos seus Princípios de Política, não por acaso publicado na mesma época. Da mesma forma, vez que a necessidade de adaptação do governo às mudanças sociais determinadas pela opinião pública impunham interpretações constitucionais mais conforme o espírito liberal do que com a letra da lei, para Benjamin Constant não era necessário que o Poder Moderador fosse formalmente consagrado no texto como um quarto poder, desde que ela fosse observada na prática institucional empírica. Durante os quinze anos de vida que lhe restaram, o autor de Adolphe sempre interpretou o papel constitucional do rei da França de acordo com o Poder Moderador por ele teorizado, deixando em segundo pla- 
no a literalidade dos enunciados normativos da Carta de $1814^{22}$ que, guiados em uma lógica mais de limitação da potência soberana do que de repartição do poder (Waresquiel e Yvert, 2002:58), atribuíam ao príncipe vastos poderes governamentais. Isto posto, o fato de atribuir constitucionalmente ao monarca o exercício do Poder Executivo (como se fizera na França, na Espanha, em Portugal, na Holanda e na Bélgica) não consistia, para ele, em nenhum óbice para o funcionamento de sua teoria, desde que os negócios ordinários da administração ficassem, na prática, por conta de um ministério responsável ${ }^{23}$. Nesse ponto a Constituição brasileira foi inclusive cuidadosa ao não confundir o imperador com o próprio Poder Executivo, fazendo daquele apenas o seu chefe e acrescentando que ele apenas o exercia por meio de seus ministros de Estado (art. 102), sem cuja referenda os atos assinados pelo rei não teriam executoriedade (art. 132) ${ }^{24}$.

A segunda objeção é que a visão tradicional da historiografia brasileira parece tomar por equivalentes conceitos como parlamentarismo e sistema representativo. A publicística francesa da década de 1820 não falava em parlamentarismo, e sim de governo representativo, gênero cuja espécie por excelência era a monarquia constitucional ou monarquia representativa. Se por sistema parlamentar se deve compreender a escolha e a duração de governos a partir da vontade da maioria legislativa, ficou provado recentemente que, nesse caso, esse governo jamais existiu na França durante o período em estudo (1815-1830). Amparado na Constituição, o príncipe estava livre para nomear quem bem entendesse, independentemente do humor das câmaras; por outro lado, dele dependia, igualmente, a vida legítima dos ministérios. A única arma do Legislativo era uma oposição tenaz que, na forma de sucessivas obstrução ou derrotas, convencesse o ministério da inutilidade de continuar pelejando. Aos poucos, os ministros começaram a se conscientizar que, dado o grau de divergência ideológica dos partidos parlamentares, eles careciam do apoio da maioria se quisessem governar a contento -0 que estava longe de constituir um regime parlamentarista, pois noções suas elementares eram ainda embrionárias (Laquièze, 2002) ${ }^{25}$. Também não havia consenso acerca da oportunidade ou utilidade dos poucos mecanismos parlamentares que se ensaiavam, como o direito de petição, a resposta à fala do trono ou o pedido de esclarecimentos aos ministros - logo incorporados, por imitação, à prática brasileira. Por não estar sistematizada nem mesmo na literatura política inglesa, essa concepção do governo representativo não se encontra em nenhuma das obras sobre o Poder Moderador escritas no período. Mesmo para 
Constant, a noção parlamentar de responsabilidade política não era clara, como se vê de sua dificuldade de dissociar sanção jurídica e perda de confiança no ambiente parlamentar (Rosanvallon, 1994:87) ${ }^{26}$. O que os liberais pleiteavam, nas décadas de 1810 e 1820, era a necessidade de um intercâmbio, uma comunhão de vistas entre governo e parlamento, ficando o rei encarregado de, em caso de desinteligência acentuada, resolver discricionariamente os conflitos. Ir além disso e sustentar, portanto, que os teóricos liberais do Poder Moderador tinham em mente o parlamentarismo como sistema de governo é deles exigir dons adivinhatórios, que não poderiam ter.

A terceira objeção referente à suposta deformação da doutrina do Poder Moderador pode ser desenvolvida a partir da comparação das prerrogativas outorgadas ao imperador pela Constituição de $1824 \mathrm{com}$ aquelas que Constant lhes havia reservado e que podiam ser conhecidas da elite política brasileira. Dez anos antes, nas Reflexões sobre as Constituições e as Garantias, com um Esboço de Constituição, Constant elencara sete atribuições régias inerentes ao poder neutro: a nomeação e exoneração de ministros, a sanção dos projetos de lei (com poder de veto absoluto), o adiamento e a dissolução das câmaras, a nomeação dos membros do Poder Judiciário, o poder de agraciar réus condenados e o direito de declarar a guerra e fazer a paz (Constant, 1861:182). No ano seguinte, ao publicar, durante os Cem Dias, os Princípios de Politica Aplicáveis a todos os Governos Representativos e Particularmente à Constituição atual da França, o número de atribuições do Poder Moderador caiu de seis para quatro: nomear e destituir ministros, criar novos pares, dissolver a câmara baixa, e conceder graça (Constant, 1997:323). Na verdade, na medida em que costumavam ser incluídas entre as do Executivo nas poucas monarquias constitucionais então existentes, não havia entre elas nenhuma atribuição que se possa considerar nova do ponto de vista jurídico - a única novidade consistia em agrupá-las em um poder distinto. Aquelas duas obras foram reunidas em 1818, juntamente com outras tantas de Constant, em uma vasta coletânea que, publicada como Coleção Completa de Obras Publicadas sobre o Governo Representativo e a Constituição Atual da França, Formando uma Espécie de Curso de Política Constitucional, foi a mídia pela qual o público brasileiro teve conhecimento de sua doutrina ${ }^{27}$. Dentre todas essas atribuições do poder neutro, que, aí reunidas, poderiam ser portanto legitimamente incorporadas ao texto da Constituição, as únicas alterações significativas promovidas pelo Conselho de Estado foram a adição da concessão de anistia e a transferência da prerrogativa de guerra e paz 
para o título do Poder Executivo - o que implicava eliminar a discricionariedade no exercício daquela atribuição, que passava a se submeter ao crivo dos ministros e do Legislativo.

No mais, o trabalho dos conselheiros foi de mera adaptação de outras competências às circunstâncias brasileiras e às demais instituições previstas na Constituição - assim, o direito de nomear pares hereditários foi substituído pelo de escolher senadores vitalícios, a partir de uma lista tríplice de eleitos em cada província (conforme aliás constava da proposta original monarquiana, de 1789); o direito de nomear juízes, por sua vez, foi substituído pelo de suspendê-los quando acusados de corrupção, mas somente depois do contraditório; por fim, o direito de veto sobre os projetos de lei foi estendido àqueles que viessem a ser elaborados pelos conselhos provinciais, que na França não existiam por conta da total centralização político-administrativa. Todas as alterações efetuadas nas prerrogativas do Poder Moderador foram, portanto, no sentido de torná-las ainda mais liberais e de proporcionar ao seu exercício uma maior possibilidade de controle qualitativo, cujo exemplo máximo foi a obrigatoriedade da oitiva prévia do próprio Conselho de Estado, ainda que consultiva (art. 142). A afirmação de que semelhantes adaptações teriam "desfigurado" a doutrina de Constant, dando-lhe feições autoritárias, não passa, assim, de um contra-senso evidente ${ }^{28}$.

A verdade, dessa forma, é que o imperador e os conselheiros de Estado lograram operar uma transposição jurídica bastante fiel para o Poder Moderador imperial das competências concedidas por Benjamin Constant ao seu poder neutro ou régio. Assim, não é no campo normativo do direito constitucional que pode repousar a verdadeira divergência dos conselheiros de Estado perante os ensinamentos de Constant, e sim no campo das intenções monarquianas que estavam por trás do texto da lei. É nesse último terreno que devem ser encarados os artigos doutrinários que foram enxertados na Constituição - em especial, o de número 11, que proclamou a dualidade da representação da soberania, e o art. 98, em que formalmente ocorreu uma mutação conceitual do Poder Moderador.

Vimos que, independentemente da forma constitucional como fosse qualificada, ao distinguir a autoridade inviolável (o rei) de autoridade responsável (ministério), uma das finalidades perseguidas pela doutrina liberal inscrita no Curso de Política Constitucional era a de afastar o príncipe do exercício direto da atividade governamental. Na qualida- 
de de chefe de Estado, neutro diante dos interesses políticos dos poderes diretamente constituídos, ele poderia resolver discricionária, mas também excepcional e pontualmente, as crises que eventualmente irrompessem entre eles, o que faria do príncipe não o chefe partidário da administração pública, mas o árbitro reconhecido do sistema representativo. Daí porque, conforme exposto nos Princípios de política, a distinção entre os poderes Moderador e Executivo era "la clef de toute organisation politique", ou seja, a chave, o fecho da abóbada do arcabouço institucional (Constant, 1997:324). Nesse ponto, é verdadeiramente sintomático do monarquianismo dos conselheiros de Estado que, tendo guardado impressionante fidelidade à transposição das ultraliberais atribuições jurídicas do Poder Moderador, fizeram-no, contudo121, conceituar de modo bem diverso.

De acordo com a redação do art. 98, não era mais a distinção entre os dois poderes, e sim apenas o próprio Moderador que era "a chave de toda a organização política". Embora a semelhança do enunciado pudesse eventualmente decorrer de mal-entendidos dos conselheiros, a hipótese é altamente improvável na medida em que, a crer-se em Maciel da Costa, Constant era a autoridade teórica mais lida entre os depu$\operatorname{tados}^{29}$ e qualquer leitor mediano era capaz de compreender o seu alcance. Evidência disso é que o único deputado que, durante a Constituinte, se pronunciou - provavelmente por desaviso - expressamente contra a teoria do poder neutro, sob o argumento correto de que ela enfraquecia o poder monárquico, foi justamente um dos mais aferrados à concepção monarquiana de poder - o futuro Visconde de Cairu ${ }^{30}$. Por fim, de maneira a deixar definitivamente clara a intenção embutida nessa mutação conceitual, o enunciado do artigo 98 prosseguia declarando textualmente que, delegatário privativo do Poder Moderador, o imperador tornava-se o chefe supremo e - atenção - o primeiro representante da nação. Essa afirmação peremptória da primazia do monarca resolvia, assim, o espinhoso tema da representação legítima da soberania nacional, que o art. 11 não havia resolvido ao declarar que o monarca e a assembléia eram igualmente representantes, e que na França revolucionária e na Ibéria sempre havia se resolvido, até então, em favor do Legislativo.

Na verdade, o que ocorreu é que os membros da elite coimbrã mais próximos do imperador deram-se conta de que era possível efetuar uma importação juridicamente fiel do conceito de poder neutro, atraente pela sua "modernidade" em geral e pela ênfase que conferia à inviolabilidade do imperador, combinando, porém, artigos doutrinários de 
caráter monarquiano capazes de legitimar o governo direto da Coroa, quando se tratasse de fazer o maquinário institucional sair do papel. Dela seria lícito esperar, conforme a exigência das circunstâncias, tanto um funcionamento conforme pretendido pelo liberalismo do Curso de Política Constitucional, em que o monarca era o gerente neutro do sistema representativo, quanto um regime verdadeiramente monarquiano, no qual o imperador se afirmasse como o eixo da representação nacional contra o facciosismo dos interesses particulares os quais compunham a Assembléia. O maquinário institucional poderia funcionar, na prática, tanto com Executivo forte e acima das facções, como sugeria a doutrina contida no art. 98, como também poderia operar em uma leitura parlamentarizante, em que o monarca surgia como árbitro do jogo político. Dessa combinação, foi produzido um protótipo daquilo que, ao se referir à sua proposta de um "presidencialismo intermitente", Giovanni Sartori denominou "uma máquina com dois motores alternativos" (Sartori, 1996:165). O ponto crucial do sistema residia na interpretação do art. 102, segundo o qual o imperador era chefe do Poder Executivo, exercendo-o por meio de seus ministros, e do art. $101 \mathrm{VI}$, que permitia ao príncipe, titular do Poder Moderador, livremente nomear e demitir ministros sem interferência das câmaras. Embora ambas disposições fossem compatíveis com a doutrina de Constant, poderia ocorrer - como de fato ocorreria, durante o Primeiro Reinado -, que na prática o imperador monarquianamente acumulasse o exercício dos dois poderes. Ele governaria de fato, sem que seus adversários pudessem recriminá-lo pelos desmandos decorrentes de seus atos, já que, no melhor estilo das ficções constitucionais britânicas, dado o seu caráter inviolável e sagrado (art. 99), todas as culpas deveriam recair sobre seus ministros responsáveis. Na complexa composição teórica tecida pelo governo do novo Império, a teoria liberal de Constant, do gosto do Imperador (com quem aliás se correspondia ${ }^{31}$ ), foi assim incorporada estrategicamente ao debate político, e depois ao teor da Constituição, para legitimar um projeto de corte monarquiano, julgado mais realista e em conformidade com as necessidades do país - embora este não fosse necessariamente o entendimento da oposição ${ }^{32}$.

O essencial de toda essa empreitada, repita-se, resultou portanto em um texto constitucional que permitia duas diferentes interpretações e, por conseguinte, duas formas distintas de desempenho da Coroa enquanto agência pública. Por conta dessa ambigüidade do conceito e da forma como os monarquianos brasileiros o vincularam, desde a manjedoura, à questão da construção do Estado, o tema do Poder Moderador 
cedo assumiu posição central na agenda política brasileira: a possibilidade permanente de se ativar a chave institucional monarquiana conferiria à Coroa a capacidade de eventualmente governar de modo autônomo, descolado dos interesses oligárquicos representados no Parlamento, podendo desencadear ações políticas a elas estranhas em nome de um interesse superior. A ameaça de um processo de abolição da escravatura deflagrado pela Coroa pairaria, assim, por exemplo, sob a cabeça dos interesses escravocratas durante o Primeiro Reinado (Macauley, 1993:170), acabando por concretizar-se nos finais do Segundo (Carvalho, 1996); da mesma forma, seria por pressão da Coroa que ambos os partidos tentariam sanar o problema das fraudes eleitorais por meio de reformas do sistema, cujos maiores exemplos foram a Lei dos Círculos (1856) e a Lei Saraiva (1881). Como os atributos do Poder Moderador passaram a ser identificados como sendo os do próprio Estado brasileiro, seja como realidade, discurso ou aspiração, este último passou a ser reivindicado como uma força acima da política partidária, fora do alcance e árbitra das facções, garantidora do sistema representativo e construtora da unidade nacional. No decorrer do regime, as três visões da potência discricionária da Coroa, primeiramente defendidas por Andrada e Silva, Caravelas e Queluz, continuariam a ser reivindicadas alternativa ou cumulativamente por outros atores/autores, como João Francisco Lisboa, o Visconde de Uruguai, Brás Florentino, José de Alencar e Joaquim Nabuco. Por outro lado, ela seria combatida por outros autores que, em graus também variados, postulariam o primado do Legislativo e a emancipação do interesse particular em nome da modernidade política, como Teófilo Otoni, Zacarias de Góis e Vasconcelos, Tavares Bastos e Rui Barbosa. Quando consideramos a longevidade do tema da construção do Estado brasileiro e sobretudo de nosso intermitente dilema entre autoritarismo modernizador ou liberalismo oligárquico, não parece de todo implausível que o discurso liberal monarquiano, com suas raízes no reformismo despótico-ilustrado, possa ter exercido, na conformação do discurso liberal brasileiro, impacto equivalente ao do republicanismo cívico na do liberalismo norte-americano. Nesse caso, uma melhor definição das origens intelectuais do Estado brasileiro tornaria mais fácil compreender certas formas com que parte significativa dos nossos liberais viria, por muito tempo ainda depois da independência e mesmo da República, a pensar as relações entre governo, sociedade e indivíduo entre nós.

(Recebido para publicação em janeiro de 2005) (Versão definitiva em julho de 2005) 


\section{Christian Edward Cyril Lynch}

\section{NOTAS}

1. Cabe aqui uma observação acerca do termo empregado para designar o partido dos patriotas moderados, que grande atividade teve no início da Revolução Francesa. Do fato de se reunirem então em um clube denominado sociedade dos amigos da constituição monárquica (Societé des amis de la constitution monarchique), surgiu o apelido por que ficaram conhecidos, monarchiens, expressão então sinônima de monarchistes (monarquistas), mas que ficou daí por diante historicamente associada àquele grupo político. A fim de preservar essa distinção em português, relevante, para não confundi-lo com agremiações monarquistas de orientações diversas, achei de melhor alvitre reproduzir a expressão monarquianos, adotada por Henrique de Araújo Mesquita em sua tradução do Dicionário Crítico da Revolução Francesa (Furet, 1989).

2. “Teria sido tirada dos verdadeiros princípios a idéia de separar o poder legislativo em três partes (câmaras alta e baixa, veto do Rei), das quais uma só falaria em nome da nação? Se os nobres e o rei não são representantes da nação, também não são nada no poder legislativo, pois somente a nação pode querer e, conseqüentemente, criar leis por si mesma. Qualquer um que entre no corpo legislativo só tem competência para votar pelos povos se tiver sua procuração" (Sièyes, 2001:41).

3. Daí alguns autores que, como Ran Halévi, vêem os monarquianos como seguidores de Montesquieu e admiradores da Inglaterra. Para Halévi, o representante emblemático do movimento é o moderado Mounier, ao passo que, para Griffiths, quem exprimia o "pensamento profundo" dos membros do partido era o radical Malouet. Interessante que tal não impede que o próprio Halévi sustente que Malouet era "o mais lúcido, o mais clarividente dos monarquianos" (Halévi, 1989:390).

4. "A essência mesma do monarquianismo era o postulado segundo o qual o rei devia permanecer o detentor da soberania nacional e que uma assembléia, fosse qual fosse sua forma e ainda que considerada indispensável, devia se limitar a um papel complementar, o de instruir, esclarecer o rei sobre os interesses da nação, exercendo um papel de discussão, de advertência e de conselho, preservando o rei a plenitude do poder" (Griffiths, 1988:16).

5. As expressões "elite brasiliense" e "elite coimbrã" são aqui extraídas da obra de $\mathrm{Ne}$ ves (2003:86), embora a descrição que delas faço não seja exatamente a mesma.

6. Como aponta Wilson Martins, a obra de Maciel da Costa chama-se Memória sobre a Necessidade de Abolir a Introdução dos Escravos Africanos no Brasil; sobre o Medo e Condições com que esta Abolição se Deve Fazer; e Sobre os Meios de Remediar a Falta de Braços que Ela Pode Ocasionar, Oferecida aos Brasileiros, seus Compatriotas. Publicada em Coimbra, defendia uma perspectiva econômica industrializante e também a abolição do tráfico, por contrário principalmente à segurança do Estado. Em ambos os pontos, fazia coro com Cairu (Martins, 1978:98).

7. Os liberais sempre haveriam de localizar aí a gênese do bipartidarismo imperial. Ao sustentar, em 1861, que o Partido Conservador teria sido derrotado nas eleições de 1828 (nove anos antes, portanto, de sua fundação oficial), diante da objeção do deputado Sérgio de Macedo, de que "não eram os partidos de hoje", Teófilo Ottoni replicaria: "Eram sempre os dois partidos que estão em luta em toda a parte e em todo o tempo, o partido do progresso e da conservação" (Otoni, 1979:538). 


\section{O Discurso Político Monarquiano e a Recepção do Conceito...}

8. Otávio Tarqüínio de Sousa narra a amizade estreita que os ligava: "Grandes amigos, freqüentando-se amiúde, é fora de dúvida que José Bonifácio e D. Rodrigo muitas vezes conversaram sobre os destinos e o futuro do Brasil [...]. Em data de 26 de abril de 1810, do Rio de Janeiro, dizia (Dom Rodrigo) a José Bonifácio: 'Meu amigo e senhor de minha particular veneração. [...] Nem um só instante me esqueci nem de sua amizade, nem do seu grande merecimento [...]. Sobre o seu Brasil, pode estar descansado; são grandes os seus destinos'"' (Sousa, 1974:57-58).

9. Interessante observar que a mesma imagem do Briareu foi invocada, também na mesma época, por um adversário de Andrada e Silva, o Frei Caneca, a fim de criticar os excessos por ele praticados contra a liberdade de imprensa: "Que liberdade é a nossa, se temos a língua escrava! Que perigo! Como escapar, se o Briareu do despotismo tem cem mãos, armadas de ferro, fogo, venenos e instrumentos da morte?" (Caneca, 1976:38).

10. A alusão a Napoleão Bonaparte não é gratuita. Apesar da amargura dos outros Braganças em relação a ele, Dom Pedro, espírito muito romântico, admirava-o por sua mistura de modernidade, competência político-administrativa e heroísmo militar. Ao casar-se com uma arquiduquesa austríaca, irmã de Maria Luísa, Dom Pedro tornara-se cunhado do ex-imperador francês. Depois da morte de Leopoldina, Dom Pedro casar-se-ia novamente, desta vez com uma neta da imperatriz Josefina, Amélia de Beauharnais-Leuchtemberg. O imperador tornou-se parente dos Bonaparte pelos dois lados de suas esposas, o que muito o agradava (Sousa, 1972).

11. Em fevereiro de 1823, por meio de artigo publicado sob pseudônimo, o imperador defendera a idéia de que a estabilidade das instituições somente poderia ser garantida por uma constituição curta e prática, "adaptada ao país" (Viana, 1967:58). Da mesma forma, ao abrir os trabalhos da Constituinte, ele limitara-se a falar de "uma constituição sábia, justa, adequada e executável", na qual "os três poderes sejam bem divididos" e cujas bases fossem capazes de dar "uma justa liberdade aos povos", mas também "toda a força necessária ao poder executivo" (AACB, 1823, I:16). Ainda em fins de outubro de 1823, a Coroa falaria nesses termos de governo misto, por meio de um artigo publicado pelo secretário particular do imperador, Francisco Gomes da Silva: "Ou queremos monarquia constitucional, isto é, um governo misto, ou queremos uma monarquia republicana [...]" (Viana, 1967:174).

12. O deputado "brasiliense" Cruz Gouvêia confirma a ascendência teórica de Constant no período. Ele afirma seguir "a opinião do célebre Benjamin Constant, publicista muito elogiado pelos mais ilustres deputados desta assembléia", e justifica essa preferência: ele seguia "sempre a justiça e nunca o arbítrio" (AACB, 1823, II:71).

13. Carneiro de Campos, por exemplo, não somente foi protegido de Dom Rodrigo, como foi constituído preceptor de seus filhos (Sisson, 1999:201).

14. O fato pode ser explicado em parte porque os Andradas não haviam integrado o "núcleo duro" da burocracia joanina. Esse não era o caso de Carneiro de Campos e de Maciel da Costa, desembargadores que, no segundo escalão daquela administração, haviam trabalhado diretamente com diversos ministros, como Vila Nova Portugal, Silvestre Pinheiro Ferreira e os condes de Palmela e dos Arcos (Monteiro, 1981).

15. Alguns meses mais tarde Dom Pedro, sob pseudônimo, escreveria à imprensa que o monarca merecia mais respeito dos jornais da oposição, na medida em que sua irreverência afrontaria o princípio da inviolabilidade da realeza, derivado do Poder Mo- 


\section{Christian Edward Cyril Lynch}

derador que ele já deteria, por ser, como se viu, "da essência da monarquia constitucional" . O argumento era o mesmo repetido por Andrada Machado: "Não posso levar à paciência que todos queiram e gritem Constituição e não queiram a inviolabilidade do monarca em toda a sua extensão ilimitada, como deve ser. Eu sou constitucional por princípio, já o era antes de se proclamar em Portugal; não sou como muitos que querem Constituição e sabem tão pouco o que ela é [...]. Depois que estive na Inglaterra e vi o bem executado sistema, ainda mais constitucional fiquei, vi que o Rei é um ente moral respeitadíssimo como tal e por isso inviolável; isto entendo eu, porque, sendo o Rei o poder moderador, era mister que ninguém lhe pudesse pedir contas, seus ministros é que são responsáveis por tudo, mas não de bagatelas, como agora é moda no sistema constitucional de 1791" (Viana, 1967:96).

16. A queda do gabinete Andrada, em julho, levou os três irmãos desse nome, aí incluso Andrada Machado, a fazerem oposição ao novo ministério, formado exatamente por Carneiro de Campos e Maciel da Costa. A partir daí, o paulista passou a apoiar a tese de soberania da assembléia, seja no que toca às leis ordinárias que ela produzia, seja no que toca à própria Constituição que ela haveria de produzir, refutando a tese de Carneiro de Campos.

17. O argumento é similar ao que vimos desenvolvido em 1789 por Saint-Pierre, para quem o monarca "não é apenas um comissário da nação, um doge ou um stadthouder" (Saint-Pierre, 1819:56).

18. "Alguém duvidaria que esta Assembléia é soberana, constituinte e legislativa, por ser representante da nação, cujas prerrogativas não poderiam ser comunicadas em virtude de sua indivisibilidade originária? [...] Sou reconhecido ao Imperador constitucional, a quem respeito e cuja figura farei respeitar, mas nos limites da lei [...]. O resto, é servilismo" (AACB, 1823, I:11).

19. Seria em vão que, objetivando resguardar os direitos da Coroa, Maciel da Costa sustentaria a falta de urgência dos temas sobre os quais a Câmara se debatia, invadindo competências do Executivo, às expensas de sua tarefa precípua de elaborar a constituição. Esse arriscado caminho teria tido, tanto na França, como na Espanha e em Portugal, um mesmo fim: a dissolução. "Muito desejara, Sr. Presidente, que esta ( $a$ Assembléia) se penetrasse bem do perigo que correremos em desmantelar o edifício que temos de reformar, antes de bem examinarmos suas partes e o seu todo, para não aumentarmos estorvos e dificuldades, que paralisem nossas providências com descrédito nosso e desgosto dos povos. [...] É preciso que não nos afastemos da marcha prescrita pela mesma assembléia para a ordem dos nossos trabalhos, insistindo em não fazer outras reformas salvo as que tiverem o cunho de indispensabilidade e urgência" (AACB, 1823, IV:89).

20. As exceções ficariam por conta da Câmara de Itu e de Recife. Esta última pegaria em armas logo em seguida.

21. "Tendo-nos requerido os povos deste Império, juntos em câmaras, que nós quanto antes jurássemos e fizéssemos jurar o projeto de constituição que havíamos oferecido às suas observações para serem depois presentes à nova Assembléia Constituinte; mostrando o grande desejo, que tinham, de que ele se observasse já como constituição do Império, por lhes merecer a mais plena aprovação, e dele esperavam a sua individual, e geral felicidade política: Nós juramos o sobredito projeto para a observarmos e fazermos observar, como constituição, que de ora em diante fica sendo deste Império [...]" (Bonavides e Amaral, 2002). 


\section{O Discurso Político Monarquiano e a Recepção do Conceito...}

22. Na advertência à segunda edição de suas Reflexões sobre as Constituições e as Garantias, Publicadas em 24 de maio de 1814, com um Esboço de Constituição, o próprio Constant reconhecia que, tendo-as publicado antes da outorga da Carta Constitucional, "tudo o que digo sobre o poder régio, ainda que carecendo de uma terminologia diversa daquela de nossa constituição, está perfeitamente conforme seu espírito" (Constant, 1861:169).

23. "Dir-se-á que o poder executivo emana do rei? Sem dúvida; entretanto, ainda que ele emane do rei, um tem tão pouca dependência do outro quanto do povo tem a câmara dos representantes, apesar de emanar do povo" (Constant, 1861:181).

24. Por outro lado, é preciso recordar que, mesmo nessa teoria, a influência do rei sobre o ministério era maior do que sobre os outros poderes: embora referendada por um ministro, a execução das leis dependia da sanção do príncipe, que poderia resistir a ela na medida em que o exercício da prerrogativa lhes permitia demiti-los e nomeá-los. Essa distinção entre os poderes deve ser, na prática, relativizada.

25. Muitos políticos resistiam ao que reputavam excessos de anglofilia na prática do regime, continuando a crer que respondiam pelos atos de suas pastas perante ao rei e não a um outro ministro que faria as vezes de intermediário. No Brasil, essa opinião ainda foi esposada no final da década de 1850 pelo mais ilustre constitucionalista do período, o Marquês de São Vicente - e dez anos depois do cargo de primeiro-ministro ter sido criado em lei (São Vicente, 1958:260).

26. A idéia de um gabinete solidariamente responsável perante as câmaras, gozando de maioria parlamentar e liderado pelo mais prestigioso de seus ministros, que governaria até que a confiança da maioria parlamentar se desfizesse, sob a forma de um voto de reprovação, começou apenas a se desenhar sob a monarquia de Julho, ao passo que a teoria clássica do sistema parlamentar de governo só ficou assentada na Inglaterra na década de 1860, quando Stuart Mill e Bahegot associaram o conceito de governo representativo ao de sistema parlamentar, e na França sob a Terceira República, quando Barthélemy, Duguit, Esmein e outros forjaram o conceito jurídico de parlamentarismo (Laquièze, 2001), até então, a mais das vezes, expressão pejorativamente usada pelos conservadores.

27. Essa edição foi utilizada até 1861, quando foi substituída por uma segunda edição, prefaciada por Édouard Laboulaye, destinada a, em outro contexto, alimentar o debate liberal contra a autocracia de Napoleão III.

28. Por outro lado, nas obras assinaladas, Constant não se debruçara de modo claro acerca da necessidade ou não de carecerem de referenda ministerial os atos específicos do Poder Moderador - certamente porque, não tendo ainda a França a prática da monarquia representativa, essa questão (que futuramente geraria tanta celeuma no Brasil e em Portugal) não pudera ainda evidentemente se converter em um problema.

29. "Entre os modernos temos Bacon, que diz e demonstra que as reformas das instituições de um povo são mais obras do tempo do que do gabinete; temos Montesquieu, João Jacques, Montlosier, Benjamin Constant, que suponho hoje nas mãos de todos [...]" (AACB, 1823, IV:94).

30. "Este (Constant) escritor não é o meu homem; pois [...] é pelo seu insidioso sistema de fazer o ministério ter as atribuições do poder executivo, figurando o monarca constitucional mero poder neutro, que, no meu entender, ele viria a ser, a pretexto de sagrado e inviolável, uma autoridade nula" (AACB, 1823, IV:28, ênfases minhas). 


\section{Christian Edward Cyril Lynch}

31. Dom Pedro I autoproclamava-se liberal pelo menos desde os 20 anos de idade, sob o Absolutismo, portanto. Era ainda leitor e admirador das obras de Filangieri e de Constant, batendo-se pelo constitucionalismo nos jornais, sob diversos pseudônimos (Sousa, 1972). Mesmo depois, ambos trocariam cartas; para Constant, Dom Pedro era um verdadeiro herói do liberalismo.

32. Assim se referiria Frei Caneca ao Poder Moderador: "O poder moderador de nova invenção maquiavélica é a chave mestra da opressão da nação brasileira e o garrote mais forte da liberdade dos povos. Por ele, o Imperador pode dissolver a câmara dos deputados, que é a representante do povo, ficando sempre no gozo dos seus direitos o senado, que é a representante dos apaniguados do Imperador [...], ficando o povo indefeso nos atentados do Imperador contra os seus direitos [...]" (Caneca, 1976:70).

\section{REFERÊNCIAS BIBLIOGRÁFICAS}

ANDRADA E SILVA, José Bonifácio de. (1998), Projetos para o Brasil (organização de Miriam Dolhnikoff). São Paulo, Companhia das Letras.

BONAVIDES, Paulo e AMARAL, Roberto. (2002), Textos Políticos da História do Brasil. Brasília, Senado Federal.

e ANDRADE, Paes. (1991), História Constitucional do Brasil (3ª ed.). Rio de Janeiro, Paz e Terra.

BREDIN, Jean-Denis. (1988), Sièyes - La Clé de la Révolution Française. Paris, Éditions de Fallois.

CANECA, Joaquim do Amor Divino Rabelo, o Frei. (1976), Ensaios Políticos: Crítica da Constituição Outorgada, Bases para a Formação do Pacto Social e Outros. Rio de Janeiro, Editora PUC-Rio.

CARNEIRO DA CUNHA, Pedro Octavio. (1985), "A Fundação de um Império Liberal", in S. B. de Holanda (org.), História Geral da Civilização Brasileira (6ª ed.). São Paulo, Difel, Tomo II, vol. 1.

CARVALHO, José Murilo de. (1993), A Monarquia Brasileira. Rio de Janeiro, Ao Livro Técnico.

(1996), A Construção da Ordem: A Elite Política Imperial; Teatro de Sombras: A Política Imperial. ( $2^{a}$ ed. rev.). Rio de Janeiro, Editora UFRJ/Relume Dumará.

CARVALHO, M. E. Gomes de. (1979), Os Deputados Brasileiros nas Cortes de Lisboa. Brasília, Senado Federal.

CHATEAUBRIAND, François-René. (1987), Chateaubriand Politique. Paris, Hachette Pluriel (textos escolhidos, apresentados e anotados por Jean-Paul Clément).

CONSTANT, Benjamin. (1861), Cours de Politique Constitutionnelle (2 $2^{\mathrm{a}}$ ed.). Paris, Guillaumin (prefácio de Édouard Laboulaye). 


\section{O Discurso Político Monarquiano e a Recepção do Conceito...}

(1997), "Principes de Politique Applicables à tous les Gouvernements Représentatifs et Particulièrement à la Constitution Actuelle de la France", in Ecrits Politiques. Paris, Gallimard (introdução de Marcel Gauchet).

DUPUY, Roger e MORABITO, Marcel. (1995), 1795 - Pour une République sans Révolution. Rennes, Presses Universitaires de Rennes.

FAORO, Raymundo. (1997), Os Donos do Poder - Formação do Patronato Político Brasileiro. Rio de Janeiro, Editora Globo.

FAUSTO, Bóris. (1999), História do Brasil (7ª ed.). São Paulo, Editora da USP.

FUNCHAL, Marquês de. (1908). O Conde de Linhares - Dom Rodrigo Domingos Antônio de Sousa Coutinho. Lisboa, Tipografia Bayard.

FURET, François (org.). (1989). Dicionário Crítico da Revolução Francesa. Prefácio da edição brasileira de José Guilherme Merquior. Tradução de Henrique de Araújo Mesquita. Rio de Janeiro, Nova Fronteira.

e HALÉVI, Ran. (1996), La Monarchie Républicaine - La Constitution de 1791. Paris, Fayard.

GAUCHET, Marcel. (1995), La Révolution des Pouvoirs. Paris, Gallimard.

GIRARD, Louis. (1984), Les Libéraux Français, 1815-1875. Aubier, Collection Historique.

GRIFFITHS, Robert. (1988), Le Centre Perdu: Malouet et les Monarchiens dans la Révolution Française. Grenoble, Presses Universitaires de Grenoble.

HALÉVI, Ran. (1989), “Monarquianos”, in F. Furet e M. Ozouf (orgs.), Dicionário Crítico da Revolução Francesa. Rio de Janeiro, Nova Fronteira (prefácio de João Guilherme Merquior; tradução de Henrique de Araújo Mesquita).

JAVARI, Barão de (org.). (1993), Império Brasileiro: Falas do Trono, desde o Ano de 1823 atéo Ano de 1889, Acompanhadas dos Respectivos Votos de Graça da Câmara Temporária e de Diferentes Informações e Esclarecimentos sobre todas as Sessões Extraordinárias, Adiamentos, Dissoluções, Sessões Secretas e Fusões com um Quadro das Épocas e Motivos que deram Lugar à Reunião das Duas Câmaras e Competente Histórico, Coligidas na Secretaria da Câmara dos Deputados (Prefácio de Pedro Calmon). Rio de Janeiro, Editora Itatiaia.

LANJUINAIS, Jean-Denis, Conde de. (1832), "Constitutions de la Nation Française", in Oeuvres de J.-D. Lanjuinais, pair de France, membre de l'Institute, etc., avec une notice biographique, par Victor Lanjuinais. Tome deuxième. Paris, Dondey-Dupré Père et Fils, Imprim.-Libraires.

LAQUIÈZE, Alain. (2002), Les Origines du Régime Parlementaire en France (1814-1848). Paris, PUF.

LIRA, Augusto Tavares de. (1979), Instituições Políticas do Império. Brasília, Senado Federal.

LUSTOSA, Isabel. (2000), Insultos Impressos: A Guerra dos Jornalistas na Independência 1821-1823. São Paulo, Companhia das Letras.

MACAULEY, Neill (1993). Dom Pedro I - A Luta pela Liberdade no Brasil e em Portugal 1798-1834. Tradução de André Villalobos. Rio de Janeiro, Record. 


\section{Christian Edward Cyril Lynch}

MALOUET, Pierre-Victor. (1996) [1789], "Discours de Malouet sur la Sanction Royale", in F. Furet e R. Halévi, La Monarchie Républicaine - La Constitution de 1791. Paris, Fayard.

MARTINS, Wilson. (1978), História da Inteligência Brasileira. São Paulo, Cultrix, Editora da USP.

MAXWELL, Kenneth. (2001), A Devassa da Devassa - A Inconfidência Mineira: Brasil-Portugal-1750-1808 (5ํe․). Rio de Janeiro, Paz e Terra (tradução de João Maia).

MIRABEAU, Honoré Gabriel Ritequi. (1996) [1789], “Discours de Mirabeau sur le Droit de Veto", in F. Furet e R. Halévi, La Monarchie Républicaine - La Constitution de 1791. Paris, Fayard.

MONTEIRO, Tobias. (1981), História do Império: A Elaboração da Independência. Belo Horizonte, Itatiaia.

MOUNIER, Jean-Joseph. (1996), “Discours de Mounier sur la Sanction Royale”, in F. Furet e R. Halévi, La Monarchie Républicaine - La Constitution de 1791. Paris, Fayard.

NEVES, Lúcia Maria Bastos Pereira das. (2003), Corcundas e Constitucionais: A Cultura Política da Independência (1820-1822). Rio de Janeiro, Revan.

OLIVEIRA, Cecília Helena de Salles. (1999), A Astúcia Liberal: Relações de Mercado e Projetos Políticos no Rio de Janeiro (1820-1824). Bragança Paulista, EDUSF/ÍCONE.

OTONI, Teófilo. (1979), Discursos Parlamentares. Brasília, Câmara dos Deputados (seleção e introdução de Paulo Pinheiro Chagas).

PARADOL, Prévost. (1981), La France Nouvelle et Pages Choisis. Paris, Éditions Garbier Frères (apresentação e notas de Pierre Guiral).

POCOCK, John. (1975), The Machiavellian Moment: Florentine Political Thought and the Atlantic Republican Tradition. Princeton, Princeton University Press.

RIALS, Stéphane. (2002) [1982], Textes Constitutionnels Français (17ª ed.). Paris, Presses Universitaires de France.

ROSANVALLON, Pierre. (1994), La Monarchie Impossible: Les Chartes de 1814 e 1830. Paris, Fayard.

. (2002), Leçon Inaugurale Faite le Jeudi 28 mars 2002. Chaire d'Histoire Moderne et Contemporaine du Politique. Paris, Collège de France.

SAINT-PIERRE, Jacques-Henri Bernardin de. (1819) [1789], Les Voeux d'un Solitaire. Paris.

SIÈYES, Emmanuel-Joseph. (1996) [1789], “Dire de l'Abbé Sièyes sur la Question du Veto Royal”, in F. Furet e R. Halévi, La Monarchie Républicaine - La Constitution de 1791. Paris, Fayard.

. (2001) [1789], A Constituinte Burguesa (sic) - Qu'est-ce le Tiers Etat? (4ª ed.) Organização e introdução de Aurélio Wander Bastos. Prefacio de José Ribas Vieira. Tradução de Norma Azevedo. Rio de Janeiro, Lumen Juris.

SÃO VICENTE, José Pimenta Bueno, Marquês de. (1958) [1857], Direito Público Brasileiro e Análise da Constituição do Império. Rio de Janeiro, Ministério da Justiça. 
O Discurso Político Monarquiano e a Recepção do Conceito...

SARTORI, Giovanni. (1996), Engenharia Constitucional - Como Mudam as Constituições. Brasília, Editora Universidade de Brasília.

SISSON, S. A. (1999), Galeria dos Brasileiros Ilustres. Brasília, Senado Federal.

SOUSA, Otávio Tarqüínio de. (1972), Vida de Dom Pedro I. São Paulo, Melhoramentos. (1974), Vida de José Bonifácio. Rio de Janeiro, José Olímpio.

VIANA, Hélio. (1967), Dom Pedro I Jornalista. São Paulo, Melhoramentos.

WARESQUIEL, Emmanuel de e YVERT, Benoît. (2002), Histoire de la Restauration. Paris, Editions Perrin.

\section{Periódicos consultados:}

AACB (1823). Anais da Assembléia Constituinte Brasileira.

AS (1841). Anais do Senado.

DACB (1823). Diários da Assembléia Constituinte Brasileira. 


\begin{abstract}
Monarchical Political Discourse and Receptiveness to the Concept of a Moderating Power in Brazil (1822-1824)
\end{abstract}

This article revisits the founding moment of Brazilian political institutions in order to highlight the penetration of French monarchical discourse among statesmen connected to the Brazilian Crown. The concept of a moderating power was thus mobilized strategically by these statesmen to safeguard the Crown's prerogatives from the growing interference of the 1823 Constitutional Congress. The objective was to justify the preeminence of the Prince over Parliament as representative of the nation's sovereignty. This justification introduced new semantic meanings into the concept, such as those of active neutrality, discretionarity, and centralization, which came to be identified with the state itself during the state-building process. The result was that the legal text allowed a monarchical reading of the Chief of State as an axis for government activity, but also another, ultraliberal reading in which he appeared merely as arbiter of the Constitutional system.

Key words: Constitutionalism; French monarchical discourse; state-building; Constitutional monarchy; moderating power; neutrality; centralization; discretionarity

\title{
RÉSUMÉ
}

Le Discours Politique Monarchiste et l'Accueil de l'Idée de Pouvoir Modérateur au Brésil (1822-1824)

Dans cet article, on réexamine le moment fondateur des institutions politiques brésiliennes afin de souligner l'influence du discours monarchiste français sur les hommes d'État liés à la Couronne brésilienne. Ils se seraient servis stratégiquement de l'idée de pouvoir modérateur dans le but de sauvegarder les prérogatives de la Couronne contre les ingérences croissantes de l'Assemblée constituante de 1823, c'est-à-dire justifier la primauté du Prince, comme représentant la souveraineté de la nation, sur le Parlement. Ce but a permis d'assimiler à cette idée de nouveaux sens sémantiques tels que: neutralité active, caractère arbitraire et centralisateur, qui se sont identifiés à l'État naissant. Il en résulte que le texte légal rend possible non seulement une lecture monarchiste du chef de l'État comme axe du gouvernement, mais aussi une autre, ultralibérale, où il ne serait que l'arbitre du système constitutionnel.

Mots-clé: constitutionnalisme; discours monarchiste français; construction de l'État; monarchie constitutionnelle; pouvoir modérateur; neutralité; centralisation; caractère arbitraire 